\title{
Modelling ecological change over half a century in a subtropical estuary: impacts of climate change, land-use, urbanization and freshwater extraction
}

\author{
Scott A. Condie ${ }^{1, *}$, Donna Hayes ${ }^{1}$, Elizabeth A. Fulton ${ }^{1}$, Marie Savina ${ }^{2}$ \\ ${ }^{1}$ CSIRO Wealth from Oceans Flagship, GPO Box 1538, Hobart, Tasmania 7004, Australia \\ ${ }^{2}$ CSIRO Wealth from Oceans Flagship, GPO Box 2583, Brisbane, Queensland 4001, Australia
}

\begin{abstract}
The Clarence River Estuary is the largest estuary in southeast Australia, with an extensive floodplain encompassing multiple river channels and a large coastal lagoon. It is the focus of major commercial and recreational fisheries and there is pressure to divert its freshwater inputs for agricultural and domestic uses. We used a spatial biogeochemical model to simulate the variability and evolution of this system on timescales from days to decades over the past half century. Like most tropical and subtropical estuaries, the Clarence River Estuary is strongly influenced by river discharge, sediment and nutrient loads. Given the high nutrient loads arriving from the upper catchment, plankton biomasses in the model were typically limited by flushing through the estuary channels. However, the longer residence times of the lagoons produced a profoundly different regime where higher zooplankton concentrations were supported by recycling of nutrients and detritus. Using alternative model scenarios, it was found that the ecology of the lagoon was sensitive to changes in land-use and urbanization within the local sub-catchment, but was largely insensitive to changes in upstream river discharge (i.e. rainfall or freshwater extraction). The opposite was true in the estuary channels, where changes in land-use or urbanisation in the populated lower catchment had little effect on the estuarine ecology, while even modest reductions in river discharges dramatically increased the biomass of the smaller phytoplankton and zooplankton groups, and favoured benthic algae over seagrass and macroalgae. The contrasting responses of these 2 estuarine environments suggests the need for distinct management approaches, with stringent controls on nutrient loads into coastal lagoons and protection of environmental flows into estuary channels.
\end{abstract}

KEY WORDS: Coastal lagoon $\cdot$ Flushing $\cdot$ Land-use $\cdot$ Climate impacts $\cdot$ Nutrients $\cdot$ Phytoplankton · Zooplankton

\section{INTRODUCTION}

As in many parts of the world, estuaries along Australia's entire east coast have experienced increasing pressures over the past half-century associated with rising human populations. These pressures have included increased demands on resources (freshwater, fish stocks, shoreline and aquatic habitats) from the cumulative effects of agriculture, forestry, commercial and recreational fishing, and residential and industrial development (Eyre 1998a, 2000, Harris 2001, Roy et al. 2001, Gillanders \& Kingsford 2002, Brodie \& Mitchell 2005, Hamilton \& Gehrke 2005). In subtropical systems, these impacts have been further compounded by declining rainfall and other climatic changes over the past 50 years (Preston \& Jones 2008, Bureau of Meteorology 2011).

Changes in rainfall, river discharge and flushing rate may have profound implications for the ecology of subtropical estuaries. Links between flushing and 
phytoplankton responses have been identified in many temperate estuaries (e.g. Alpine \& Cloern 1992, Basu \& Pick 1996, Lucas et al. 1999), and the effects in subtropical estuaries may be even larger due to higher variability in river discharge rates. A comparative study of 9 subtropical estuaries in eastern Australia supported this suggestion and identified a number of flow regimes controlling biogeochemical processes (Eyre 2000). Recent studies of subtropical estuaries entering the Gulf of Mexico also found that major flow events initially inhibited phytoplankton growth before providing a stimulatory effect as the estuary recovered (Murrell et al. 2007, Lehrter 2008). Flushing of the subtropical Pearl River Estuary (separating Macau and Hong Kong) also inhibits phytoplankton growth and appears to be the major factor in limiting levels of eutrophication under the high nutrient loads arriving from catchments in southern China and coastal cities (Yin 2002, Harrison et al. 2008).

The Clarence River Estuary in northern New South Wales (NSW) is the largest estuary in southeast Australia and the most significant from a fisheries perspective (Pease \& Grinberg 1995), supporting major commercial and recreational fisheries targeting species such as school prawns Metapenaeus macleayi, eastern king prawns Melicertus plebejus, mud crabs Scylla serrata, and a wide variety of finfish. It is characterised by a large floodplain encompassing multiple river channels, a cut-off embayment (Roy et al. 2001) and a large coastal lagoon (Fig. 1). Coastal lagoons represent a distinct environment from estuarine channels, and in NSW represent only around $1.5 \%$ of the total wetland area (Kingsford et al. 2004). The ecosystem services provided by such environments have been widely recognised (Woodward \& Wui 2001) and are known to include moderating water quality (Faulkner 2004), providing key feeding and nursery habitats (Paerl 2010), and supporting coastal and offshore fisheries (Ansari et al. 2003). While a critical balance between nutrient loads and flushing rates in coastal lagoons has been demonstrated (Webster \& Harris 2004), much remains to be understood in terms of their links to other parts of the estuarine system and their responses to environmental and anthropogenic changes.

In estuarine systems with high levels of natural variability and sparse intermittent monitoring, models often provide the only opportunity to explore long-term ecological changes and potential responses to future conditions, including regime shifts. In this study, we used a spatially-structured ecosystem model to simulate the variability and change in a major estuary that encompassed significant changes in both rainfall and land-use within the catchment over half a century (Preston \& Jones 2008). This has allowed us to test the hypothesis that sustained changes in river discharge can have a major impact on the ecology of subtropical estuaries and that ecological responses can differ markedly between the environments of estuary channels and coastal lagoons.

\section{MATERIALS AND METHODS}

Atlantis is a nutrient-based (i.e. biomass units of mg $\mathrm{N} \mathrm{m}^{-3}$ ) biogeochemical model that includes physical forcing, biogeochemical cycling, trophic interactions, and human influences on the ecosystem. All model variables are computed within polygonal boxes, with exchanges between adjoining boxes based on water movements (or migration where appropriate). While this is the first report of an estuarine application, Atlantis has been applied to many marine and coastal systems (Fulton et al. 2003, Fulton et al. 2005, Fulton 2010, Johnson et al. 2011) and detailed technical descriptions can be found in Fulton et al. $(2004,2007)$. Because such models involve large numbers of parameters relating physical, chemical and biological processes with varying levels of uncertainty, they have limited quantitative predictive capability, but are very effective in exploring relative trends and developing new hypotheses.

\section{Model domain and grid}

The domain of the Clarence River Estuary Atlantis Model (CREAM) started at the junction of the Clarence and Orara Rivers and extended to the mouth of the estuary (Fig. 1). It included all of the major components of the estuarine system including the main channel, other major channels (South Arm and North Arm), a coastal lagoon (Wooloweyah Lagoon), a shallow lake (The Broadwater) and significant tributaries (Sportsmans Creek, Coldstream Creek and the Esk River).

The design of the spatial structure of the model was based on a wide range of considerations including the geometry of the water body and the distributions of physical conditions (tidal regimes, stratification, salinities, sediments), habitats (benthic, water column, riparian), organisms (species, populations and communities), and human influences (resource utilisation, contaminant inputs, management zones). 


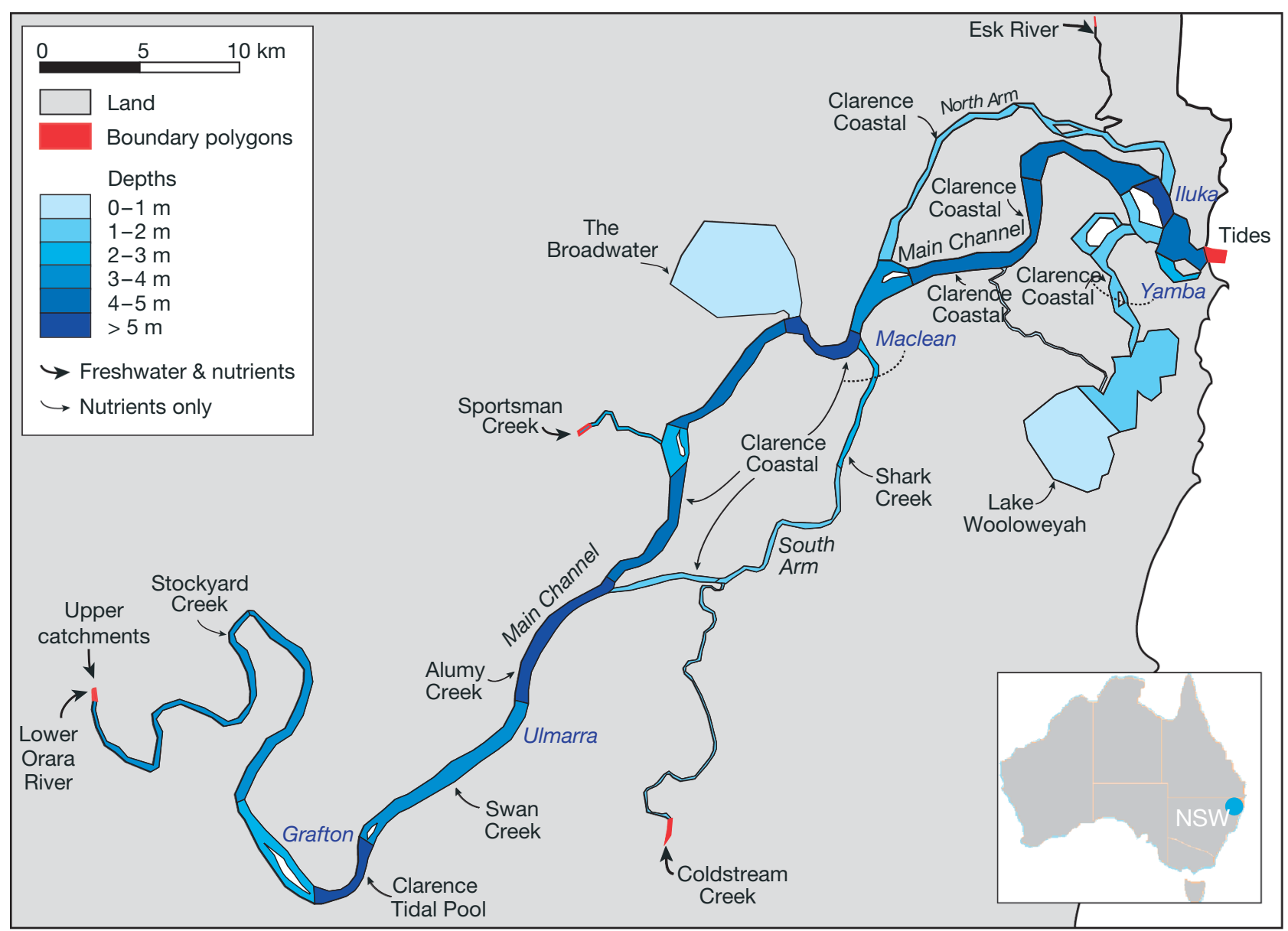

Fig. 1. The polygonal box structure of the Clarence River Estuary model indicating the depth of each box. Modelled inputs of freshwater and nutrients from the upper reaches ( $84 \%$ of the total catchment) and coastal sub-catchments (16\% of the total catchment) are also shown by arrows. The inset map shows the location of the Clarence River catchment in New South Wales (NSW), Australia

Since the estuary is known to be mostly well-mixed in the vertical, the model grid was designed with 37 polygonal boxes all extending over the full water depth (Fig. 1). A single sediment layer was also included at the base of each box. Five of the polygons were boundary boxes, where conditions were specified as forcing time-series rather than being calculated dynamically.

The temporal resolution of the model needed to be consistent with the limited spatial resolution of the model while also capturing physical and biological processes that have significant long-term effects. The model time-step was set at $1 \mathrm{~d}$, which was considered adequate to resolve variability in river flow and biogeochemical cycling. While the semidiurnal tides were not explicitly resolved, their net impact on mixing along the estuary was represented (described below). Biological processes in the model, such as primary production, were also represented as daily averages. This was consistent with the limited vertical resolution, which was not designed to resolve processes such as diurnal vertical migration.

The model was run over the period from the start of 1950 to early 2004. The first $10 \mathrm{yr}$ (1950-1959) were treated as an equilibration period in which the system could adjust from uncertain initial conditions. Since no data on river discharge or nutrient loads were available for this equilibration period, forcing was simply repeated from the 1960-1969 period. The timeframe of the model run captured an historical period of rapid regional development and environmental change in the Clarence River Valley.

\section{Physical processes}

The major physical, chemical and biological components of the model are listed in Table 1. Water tem- 
peratures in the estuary could be adequately represented by the mean seasonal cycle. However, salinity in the estuary is strongly dependent on the quantity of freshwater flowing into the system. For example, during dry periods brackish water can extend upstream as far as Grafton, while under flood conditions fresh water extends all the way to the mouth. Salinity was therefore estimated dynamically, with

Table 1. Main physical, chemical, and biological groups used in the estuary model and associated parameters determined through literature or calibration

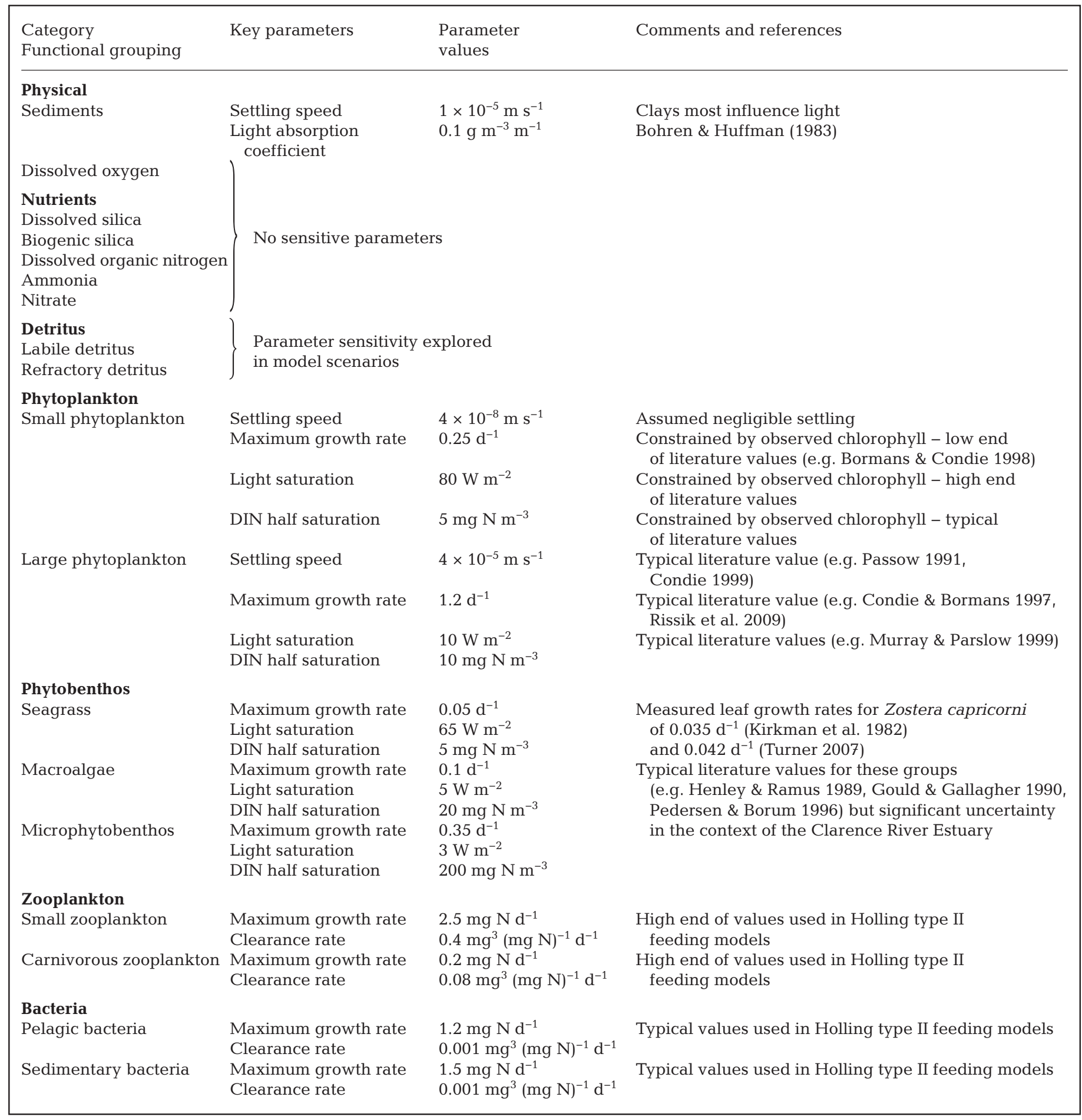


freshwater carried downstream by river flow as it mixed with seawater carried upstream by the tides.

Approximately $80 \%$ of the freshwater entering the Clarence River Estuary system comes from the upper Clarence and Orara Rivers, which join at the upstream boundary of the model. There are long-term streamflow datasets available from both of these tributaries (Manly Hydraulics Laboratory 1995) and they have been combined to provide a $44 \mathrm{yr}$ time-series of daily freshwater flux (1960 to 2004). A similar record was used to specify the freshwater flux delivered via Sportsmans Creek. Small nominal freshwater discharges were also specified for Coldstream Creek and the Esk River (20\% of the Sportsmans Creek flux). Numerous other smaller tributaries are insignificant in terms of freshwater flux, but were represented in terms of their nutrient contribution (described in 'Chemical and microbial processes' below). The average flushing time of the modelled section of estuary channels (channel volume divided by river discharge) was around $22 \mathrm{~d}$, although this fell to less than a day under flood conditions.

Physical exchanges in the estuary are also strongly influenced by tides. While tidal flows were not explicitly resolved by the daily time-step, it was critical to represent the associated upstream transport of salinity and other chemical and biological quantities. This was achieved by imposing an additional exchange between boxes that reversed direction at every time-step. The magnitude of the exchange diminished with distance upstream in direct proportion to the volume of the tidal prism (Manly Hydraulics Laboratory 2000). Because the relatively coarse resolution of the box model already imposed an unquantified level of numerical diffusive transport, the proportionality constant was used as a tuning parameter to match the salinity distribution along the estuary with observations from 1988 to 1990 (Pollard \& Hannan 1994).

Sediment transport throughout the estuary was also determined by the physical transports. A single fine sediment class was represented in the model corresponding to the clay fraction that most strongly influences light attenuation in the estuary. Sediments were introduced into the model via the river discharge and from neighbouring sub-catchments. In the absence of any information on daily sediment loads, a simple catchment model was developed for approximating daily sub-catchment loads from annual sub-catchment loads using river discharge and land-use information (see the supplement at www.int-res.com/articles/suppl/m457p043_supp.pdf). Given the underlying spatial resolution of the model, inputs from most of the sub-catchments could be adequately represented by a single point source. The exception was the Clarence Coastal sub-catchment, which surrounds a large proportion of the estuary and is intensively cultivated. It was therefore split into 7 point sources (Fig. 1).

The catchment model was run independently and the results used to force the biogeochemical model, the combination forming what Nobre et al. (2010) refer to as a multilayered ecosystem model. Once delivered into the estuary, sediments gradually settled out of the water column to be consolidated into a single layer of bottom sediment. The porosity of this layer changed in response to bioturbation and bioirrigation, which in turn influenced chemical processes in the sediments such as oxygen exchange. Resuspension of bottom sediments would be expected to increase with river discharge, but was assumed to be small in comparison and therefore not included in the model. This is a reasonable approximation for the upper estuary, but may underestimate sediment concentrations in the lower estuary under low river discharge conditions, when resuspension by winds and tides may make a significant contribution to sediment inputs.

\section{Chemical and microbial processes}

Nutrient inputs were critical in driving primary productivity levels in the model and nitrogen has been identified as the most important limiting nutrient in the Clarence River Estuary (Eyre 2000). This was represented in the model in the forms of dissolved organic nitrogen (DON) and more readily assimilated dissolved inorganic nitrogen (DIN), the latter of which split into reduced ammonia form $\left(\mathrm{NH}_{\mathrm{x}}\right)$ and oxidised nitrate form $\left(\mathrm{NO}_{\mathrm{x}}\right)$ (Table 1). Silica was also included as a potentially limiting nutrient for large phytoplankton (diatoms).

Inputs of DIN were specified in the model as a network of point sources, as described for sediments (Fig. 1). Sources near Grafton and Maclean nominally included nutrient inputs from sewage treatment plants, although these were relatively minor at the sub-catchment scale. There was limited information available on transfer of nutrients through the Clarence River Valley sub-catchments. Recent modelling conducted as part of the NSW Comprehensive Coastal Assessment provided information on subcatchment annual loads (Baginska et al. 2004). However, CREAM required estimated nutrient inputs corresponding to the daily freshwater flux data de- 
scribed above. A similar multilayered approach to that used for sediments was therefore used for approximating daily nutrient fluxes in terms of annual nitrogen loads, freshwater fluxes and land-use (see supplement).

Detritus was represented in a labile form that rapidly decomposed through remineralisation, and a refractory form that was more resistant to decomposition and subsequent biological assimilation. A detrital form of silica was also included because of its role in diatom production. A bottom sediment layer absorbed detritus settling out of the water column. Pelagic and sedimentary bacteria groups both contributed to remineralisation that made recycled nutrients (ammonia) available to other parts of the ecosystem.

Bacteria further processed the ammonia through nitrification (con-

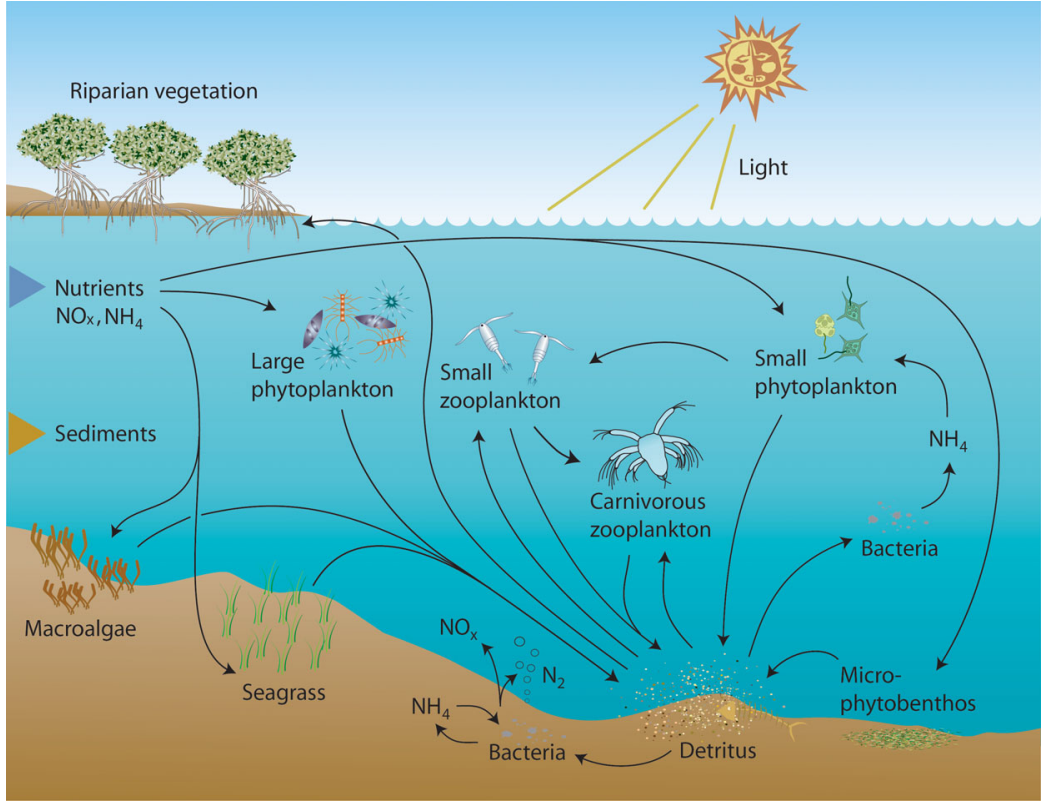

Fig. 2. Schematic representation of key components and nitrogen flows in the model associated with processes such as uptake, grazing, predation, remineralization, nitrification and denitrification

tended to be ubiquitous throughout the system. Two classes of zooplankton were represented on the basis of size and diet. Small zooplankton (e.g. copepods) consumed phytoplankton and were preyed on by larger carnivorous zooplankton (e.g. fish larvae) that also consumed detritus.

Three classes of phytobenthos were explicitly represented in the model (Table 1, Fig. 2). As flowering plants, seagrasses drew their nutrients from the soft sediments in which they grew, while microphytobenthos (benthic algae) and macroalgae (seaweeds and epiphytes) were assumed to draw their nutrients from the water column. The seagrass functional group represented 3 species found in the Clarence River Estuary (West et al. 1985): eelgrass Zostera capricorni, paddleweed Halophila ovalis, and the brackish water species ruppia Ruppia megacarpa although ruppia is not a true seagrass and appears to be restricted to The Broadwater (Manly Hydraulics Laboratory 2000). Historical surveys indicate that from 1942 to 2005 total seagrass coverage in the Clarence River Estuary fell 79\% (399 to 83 ha). No equivalent data were available to initialise biomass distributions of microphytobenthos and macroalgae in the model, so they were respectively set at nominal concentrations of $1.0 \mathrm{mg} \mathrm{N} \mathrm{m}^{-3}$ and $100 \mathrm{mg} \mathrm{N} \mathrm{m}^{-3}$, then allowed to evolve in response to conditions.

Zones of riparian vegetation, including rushes, saltmarshes and mangroves, are also common new production was nitrate limited and therefore 
throughout much of the Clarence River Estuary system, where they support communities typically dominated by detritivores (Laegdsgaard 2006). It is not clear how effective these zones are in removing dissolved nutrients, with mature systems potentially becoming nutrient sources (e.g. Polyakov et al. 2005, Drewry et al. 2006). The evidence for removal of particulate material is more compelling but still difficult to quantify across a diverse estuarine system (e.g. Laegdsgaard 2006). Riparian zones have therefore been represented implicitly as a decay term for detritus. While this is clearly a gross simplification, it did at least allow exploration of conditions characterised by both high and low concentrations of detritus.

Functional groups were linked through trophic interactions, as well as being influenced by environmental conditions in the water column and bottom sediments (Fig. 2). The main biological processes explicitly represented in the model were consumption and growth, waste production and decomposition, reproduction, bioturbation and bioirrigation, and predation and other forms of natural mortality such as disease and lysis. While the modelled foodweb was closed using a quadratic mortality term applied to carnivorous zooplankton (i.e. implicit topdown control), in model runs this trophic level was mostly limited by flushing through the estuary.

\section{Model scenarios}

A standard historical scenario was developed based on the most realistic achievable representation of recent historical trends in the estuary. The total period of the run was from January 1950 to February 2004, the first 10 years being an equilibration period. This scenario was used for model calibration.

Eight additional scenarios were run to explore the potential impacts of changes in agricultural practices and land-use, urbanisation, climate and freshwater extraction, and additional habitat disturbance or recovery (Table 2). These scenarios were run over the same nominal historical period (1950 to 2004), but varied from the standard historical scenario in their freshwater river discharges and sediment and nutrient loads to reflect possible future conditions (1 to 3 in Table 2). The exceptions were the seagrass and riparian wetland coverage scenarios $(4 \mathrm{a}, \mathrm{b}$ in Table 2), which were respectively implemented by increasing seagrass mortality and increasing the removal of labile and refractory detritus. These habitat-related scenarios were designed not only to explore potential future conditions, but also to quan- tify model sensitivities where significant uncertainties remained after calibration (by covering realistic extremes of high and low seagrass coverage, and high and low detritus concentrations).

Changes in land-use and urbanisation were assumed to begin in 1980, while changes in freshwater flow, seagrass mortality and wetland effects were applied throughout the model run (from 1950). All scenario results were contrasted with those from the historical run by comparing total biomasses for the system averaged over the 24 yr period from 1980 to 2003.

\section{RESULTS}

\section{Model calibration}

Calibration of the biogeochemical components of CREAM was based on the only detailed dataset available from the Clarence River Estuary within the modelling period, which was collected in 1996 and reported by Eyre (1998b). This was supplemented by datasets from outside the modelling period, which provided for more general comparisons of broad seasonal patterns (e.g. Rochford 1952, White 2009).

The parameters listed in Table 1 were varied systematically to identify a parameter set that provided the best match of the model variables with observed values. The key observed quantities were total suspended sediments, nitrate, ammonia and chlorophyll. Because of the limited number of observations, the calibration was performed heuristically (Fig. 3). While the observations captured only a small proportion of the potential variability in the system, the model outputs utilising the parameter values listed in Table 1 were largely consistent with observations recorded under a broad range of flow conditions. Correlations were relatively high $\left(\mathrm{R}^{2} \geq 0.68\right)$ with comparable magnitudes (slopes of 0.88 to 1.00) and normalised RMS errors not exceeding 0.17 (Table 3). While not captured directly by the observations used for calibration, the very high nitrate concentrations associated with flood events in the model (200 to $500 \mathrm{mg} \mathrm{N} \mathrm{m}^{-3}$ ) have been reported from observations during the earlier period of 1946 to 1950 (Rochford 1952).

One slightly unusual characteristic of the calibrated parameter set (Table 1) was that the maximum growth rate of small phytoplankton was significantly less than that for large phytoplankton. While many parameter combinations were tested, keeping small phytoplankton growth rates relatively low was found be essential in reproducing observed chloro- 
Table 2. Definitions of hypothetical scenarios (relative to the historical run) and summaries of their outcomes

\begin{tabular}{|c|c|c|c|}
\hline Category & Description & Implementation & Comments/references \\
\hline \multirow[t]{2}{*}{$\begin{array}{l}\text { (1) Agricultural } \\
\text { land-use }\end{array}$} & $\begin{array}{l}\text { (a) Switch to green } \\
\text { harvesting of sugarcane }\end{array}$ & $\begin{array}{l}1961 \text { to 1979: Unchanged from historical levels } \\
1980 \text { to 2003: Reduce all suspended sediment } \\
\text { and nitrogen loads by } 90 \% \text { in the Clarence } \\
\text { Coastal Catchment }\end{array}$ & $\begin{array}{l}\text { Green cane harvesting/trash } \\
\text { blanketing and minimum tillage } \\
\text { (Rayment 2003, Brodie \& Mitchell } \\
\text { 2005) }\end{array}$ \\
\hline & $\begin{array}{l}\text { (b) Major increase in } \\
\text { sugarcane production } \\
\text { levels in the Clarence } \\
\text { Valley (i.e. from approx. } \\
30 \% \text { to more than } 60 \% \text { of } \\
\text { the Clarence Coastal } \\
\text { Catchment area) assuming } \\
\text { conventional harvesting }\end{array}$ & $\begin{array}{l}1961 \text { to 1979: Unchanged from historical levels } \\
1980 \text { to 1989: Linear increase in all suspended } \\
\text { sediment and nitrogen loads in the Clarence } \\
\text { Coastal Catchment over a } 10 \text { yr period } \\
\text { to double historical loads } \\
1990 \text { to 2003: Maintained at double historical loads }\end{array}$ & $\begin{array}{l}\text { Given non-agricultural land-uses } \\
\text { and decreasing viability of } \\
\text { sugarcane away from the coast, } \\
60 \% \text { should be viewed as an } \\
\text { extreme upper limit on potential } \\
\text { production in the Clarence Valley }\end{array}$ \\
\hline \multirow[t]{2}{*}{ (2) Urbanisation } & $\begin{array}{l}\text { (a) Urban development } \\
\text { around Maclean (on main } \\
\text { channel) with a } 3 \text { yr } \\
\text { construction phase (nomi- } \\
\text { nally in } 1980 \text { to 1982) }\end{array}$ & $\begin{array}{l}1961 \text { to 1979: Unchanged from historical levels } \\
1980 \text { to 1982: Linear changes in Maclean point } \\
\text { source loads. Sediment increasing to } 100 \text { times } \\
\text { historical levels by the end of 1980, maintained at } \\
\text { that level throughout 1981, before declining } \\
\text { to historical levels by the end of 1982. Nitrogen } \\
\text { increasing to } 42 \text { times historical levels } \\
\text { by the end of } 1982 \\
1983 \text { to } 2003 \text { : Sediment loads maintained at } \\
\text { historical levels. Nitrogen loads maintained at } \\
42 \text { times historical levels at Maclean }\end{array}$ & $\begin{array}{l}\text { Assumed high sediment inputs } \\
\text { during construction and perma- } \\
\text { nent urbanisation of bushland } \\
\text { (Eqs. A3 \& A7) covering one } \\
\text { seventh of the Clarence Coastal } \\
\text { sub-catchment in the Maclean } \\
\text { area (i.e. effects one of the } 7 \text { point } \\
\text { sources). This should be viewed } \\
\text { as an extreme upper limit on } \\
\text { urbanisation }\end{array}$ \\
\hline & $\begin{array}{l}\text { (b) Urban development } \\
\text { around Oyster Channel } \\
\text { (leading into Wooloweyah } \\
\text { Lagoon) with a } 3 \text { yr } \\
\text { construction phase (nomi- } \\
\text { nally in } 1980 \text { to 1982) }\end{array}$ & As above for Oyster Channel point source & $\begin{array}{l}\text { As above for the entire } \\
\text { Wooloweyah Lagoon sub-catch- } \\
\text { ment (again an extreme upper } \\
\text { limit on urbanisation) }\end{array}$ \\
\hline \multirow[t]{2}{*}{$\begin{array}{l}\text { (3) Reduced } \\
\text { freshwater flows }\end{array}$} & $\begin{array}{l}\text { (a) Rainfall changes (or } \\
\text { extraction of freshwater) in } \\
\text { the upper catchment } \\
\text { leading to reduced fresh- } \\
\text { water, sediment and } \\
\text { nutrient loads into the } \\
\text { upper estuary as well as } \\
\text { reduced tidal exchanges } \\
\text { due to siltation }\end{array}$ & $\begin{array}{l}\text { A } 15 \% \text { reduction in freshwater, sediment and } \\
\text { nutrient loads into the western-most box of } \\
\text { the main channel, along with a } 15 \% \text { reduction in } \\
\text { physical exchanges between boxes }\end{array}$ & $\begin{array}{l}\text { Climate model projections for } \\
\text { run-off changes in the Clarence } \\
\text { catchment are mainly in the } \\
\text { range } 5 \text { to } 10 \% \text { (Preston \& Jones } \\
2008 \text { ). } 15 \% \text { was chosen as a } \\
\text { plausible upper limit }\end{array}$ \\
\hline & $\begin{array}{l}\text { (b) As above with no } \\
\text { reduction in sediment or } \\
\text { nutrient loads into the } \\
\text { upper estuary }\end{array}$ & $\begin{array}{l}\text { As above, but without any reduction in sediment } \\
\text { or nutrient loads }\end{array}$ & $\begin{array}{l}\text { Freshwater extraction occurs } \\
\text { upstream of main sediment and } \\
\text { nutrient loads }\end{array}$ \\
\hline \multirow[t]{2}{*}{ (4) Habitat change } & $\begin{array}{l}\text { (a) High seagrass mortality } \\
\text { due to trawling or other } \\
\text { effects }\end{array}$ & $\begin{array}{l}\text { Linear mortality rate of seagrass increased from } \\
0.001 \mathrm{~d}^{-1} \text { to } 0.005 \mathrm{~d}^{-1}\end{array}$ & $\begin{array}{l}\text { Spatial variations in mortality } \\
\text { have not been modelled }\end{array}$ \\
\hline & $\begin{array}{l}\text { (b) Increased extraction of } \\
\text { detritus by riparian } \\
\text { wetlands }\end{array}$ & $\begin{array}{l}\text { Decay timescale for labile and refractory detritus } \\
\text { reduced from } 12 \mathrm{~d} \text { to } 6 \mathrm{~d}\end{array}$ & $\begin{array}{l}\text { Spatial variations in wetland } \\
\text { coverage and water exchanges } \\
\text { have not been modelled }\end{array}$ \\
\hline
\end{tabular}

phyll concentrations. It is more commonly assumed that maximum mass-specific growth rate decreases with cell size (Brown et al. 2004). However, this has only been clearly demonstrated within individual phylogenetic groups of larger phytoplankton (Chen
\& Liu 2010), and the growth of diatoms can be enhanced by characteristics not explicitly represented in the model, such as vertical migration and nutrient surge uptake and storage capacity (Stolte \& Riegman 1995, Irwin et al. 2006, Verdy et al. 2009). 

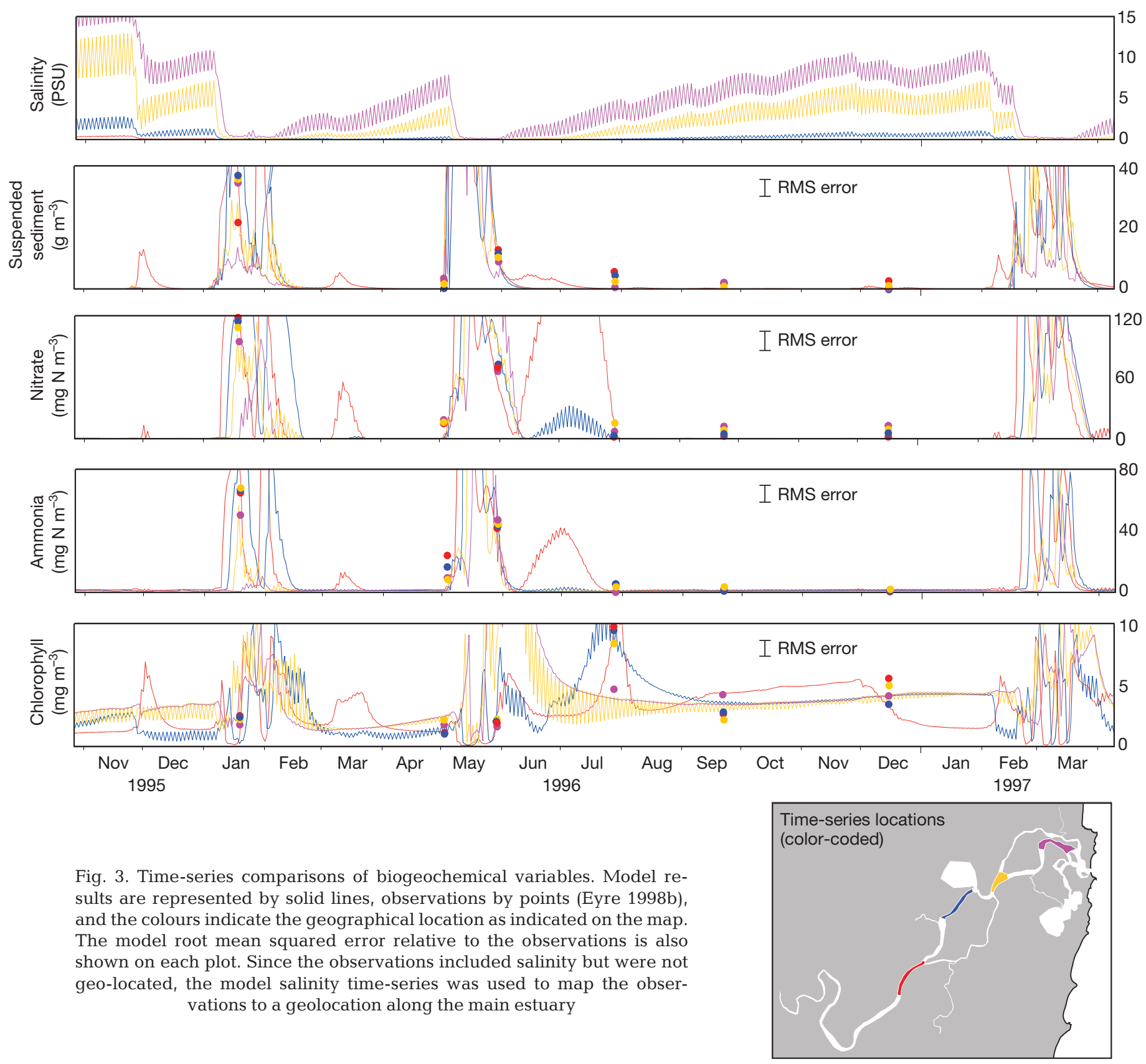

Fig. 3. Time-series comparisons of biogeochemical variables. Model results are represented by solid lines, observations by points (Eyre 1998b), and the colours indicate the geographical location as indicated on the map. The model root mean squared error relative to the observations is also shown on each plot. Since the observations included salinity but were not geo-located, the model salinity time-series was used to map the observations to a geolocation along the main estuary

While measurements taken during 2008 to 2009 in Wooloweyah Lagoon (White 2009) fall outside the modelling period, the magnitude of responses was mostly consistent with the model results. Observed nutrient concentrations were generally higher in the northern lagoon than the southern lagoon, with nitrate ranging from less than $5 \mathrm{mg} \mathrm{N} \mathrm{m}^{-3}$ during dry periods to $31 \mathrm{mg} \mathrm{N} \mathrm{m}^{-3}$ following a significant flood event. The model showed similar characteristics with an historical range of 0.5 to $22 \mathrm{mg} \mathrm{N} \mathrm{m}^{-3}$ (Fig. 4 shows 1996 outputs only). The observed ammonia concentrations (less than $5 \mathrm{mg} \mathrm{N} \mathrm{m}^{-3}$ to $109 \mathrm{mg} \mathrm{N} \mathrm{m}^{-3}$ ) reach
Table 3. Statistics comparing model outputs with the observations of Eyre (1998b). The normalised RMS error is the root mean squared error divided by the observed range

\begin{tabular}{|lccc|}
\hline & $\begin{array}{c}\text { Corre- } \\
\text { lation } \\
\left(\mathrm{R}^{2}\right)\end{array}$ & $\begin{array}{c}\text { Slope } \\
\text { (modelled over } \\
\text { observed) }\end{array}$ & $\begin{array}{c}\text { Normalised } \\
\text { RMS } \\
\text { error }\end{array}$ \\
\hline $\begin{array}{c}\text { Suspended } \\
\text { sediment }\end{array}$ & 0.79 & 0.91 & 0.15 \\
Nitrate & 0.81 & 1.00 & 0.17 \\
Ammonia & 0.81 & 0.88 & 0.17 \\
Chlorophyll & 0.68 & 0.91 & 0.15 \\
\hline
\end{tabular}


52

Mar Ecol Prog Ser 457: 43-66, 2012

(a) Medium flow

(10 March 1996) (b) Flood (10 May 1996) (c) Estuary recovery (30 May 1996) (d) Dry season (10 November 1996)

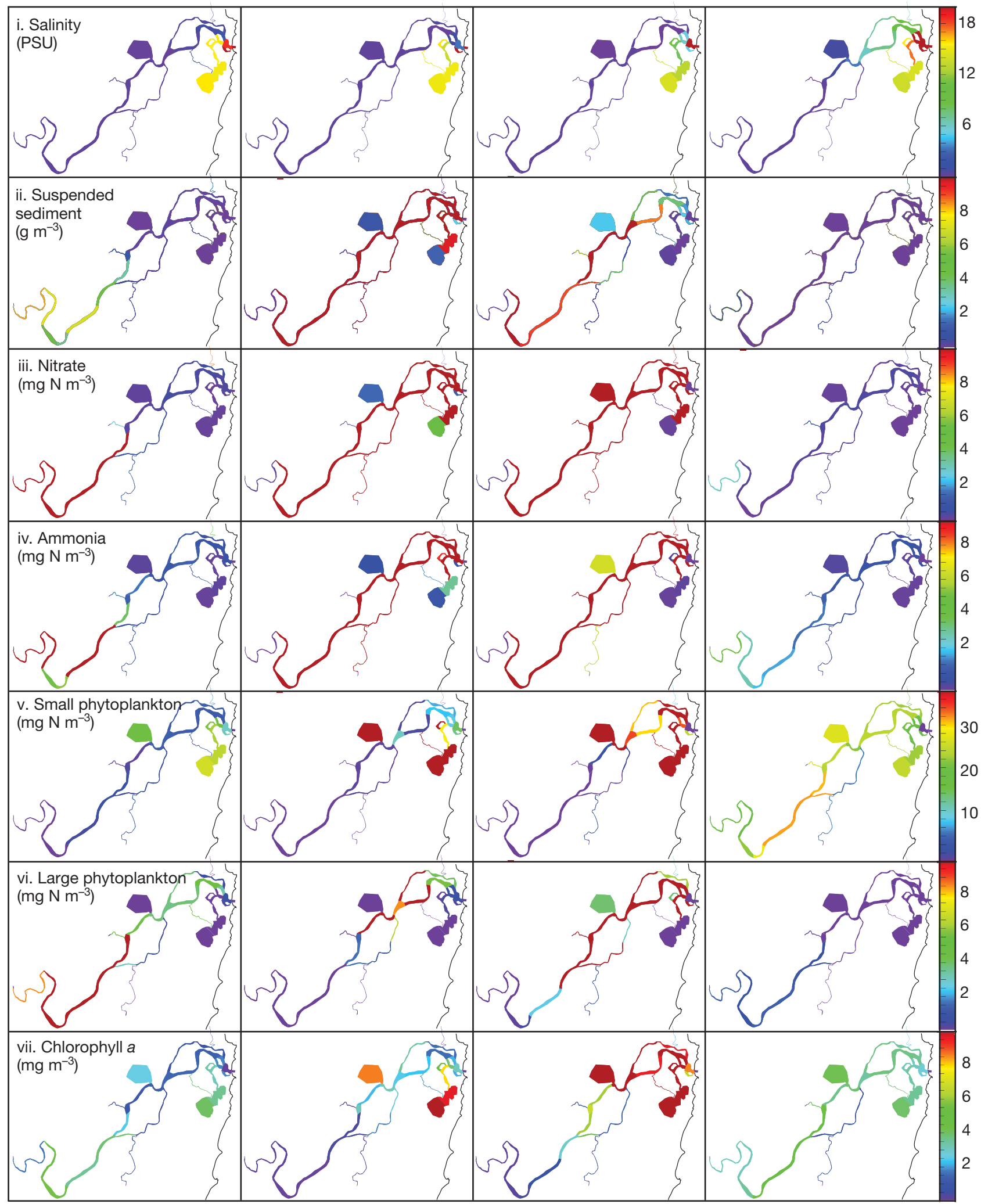

Fig. 4. Examples of model outputs under the 4 flow conditions identified by Eyre (2000), followed by the corresponding conceptual models (adapted from Eyre 2000) 


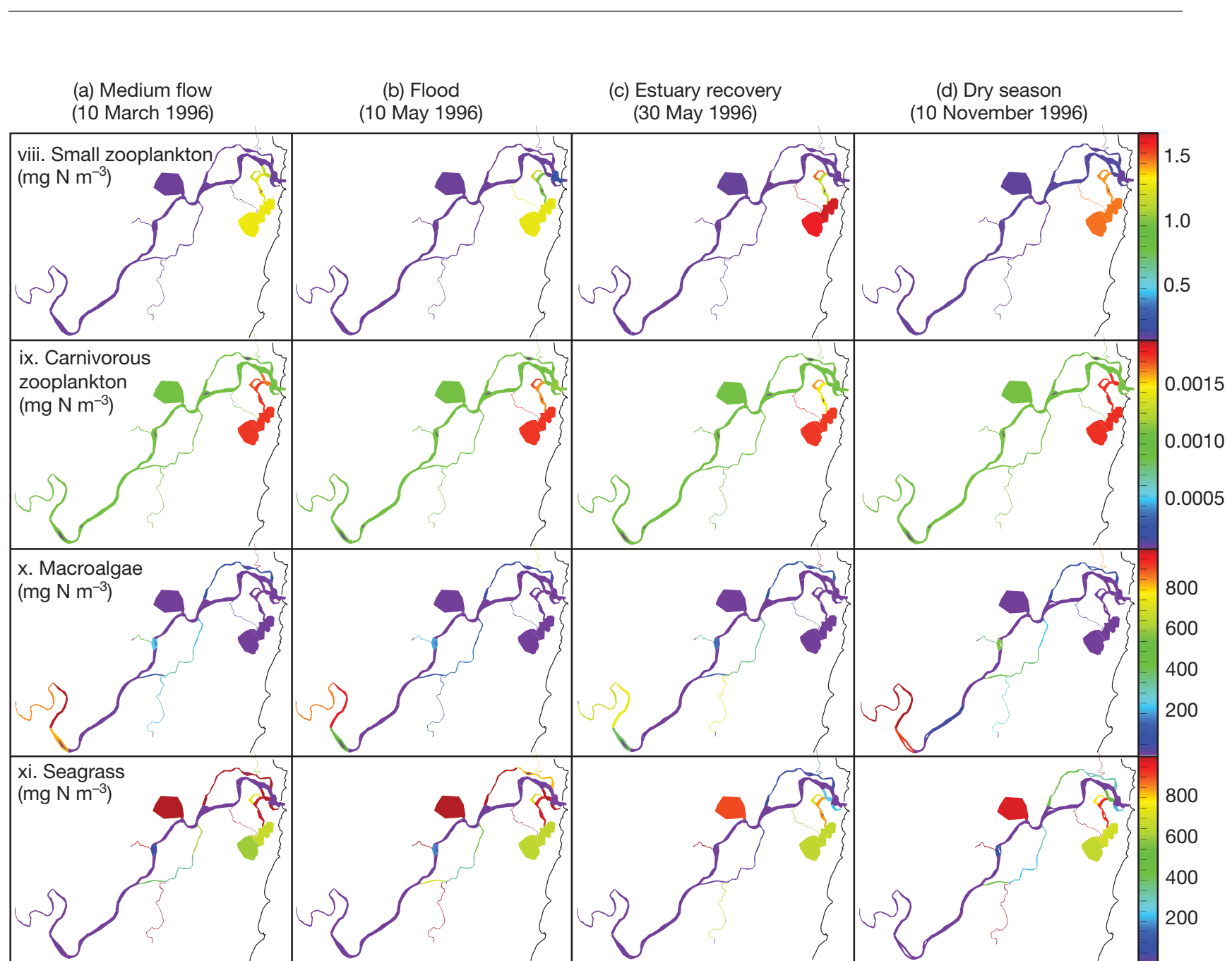

xii. Flow regimes

\begin{tabular}{|c|c|c|c|}
\hline $\begin{array}{l}\text { MEDIUM FLOW } \\
\text { Well mixed }\end{array}$ & FLOOD & $\begin{array}{l}\text { ESTUARY RECOVERY } \\
\text { Stratified to partially mixed }\end{array}$ & $\begin{array}{r}\text { DRY SEASON } \\
\text { Well mixed }\end{array}$ \\
\hline Freshwater, sediment & $\begin{array}{l}\text { Freshwater, sediment } \\
\text { \& nutrient input } \\
\text { Low light }\end{array}$ & $\rightarrow \begin{array}{c}\text { Freshwater, sediment } \\
\text { \& nutrient input } \\
\text { Light limited } \\
\begin{array}{c}\text { Low pelagic } \\
\text { productivity }\end{array}\end{array}$ & $\underset{\begin{array}{c}\text { Nutrient } \\
\text { limited }\end{array}}{\mathrm{NH}_{4} \rightarrow \mathrm{NO}_{\mathrm{X}}}$ \\
\hline $\begin{array}{l}\text { TIDAL } \\
\text { RIVER }\end{array}$ & |ESTUARY & TIDAL RIVER & \begin{tabular}{|l} 
TIDAL \\
RIVER
\end{tabular} \\
\hline
\end{tabular}

Fig. 4 (continued)

significantly higher peaks than the model ( 0.1 to $7 \mathrm{mg} \mathrm{N} \mathrm{m}^{-3}$ ). Observed chlorophyll ranged from 3 to $28 \mathrm{mg} \mathrm{m}^{-3}$ and was often higher in the southern lagoon than the northern lagoon (i.e. reverse of nutrients). This was again broadly consistent with the model results from the earlier period (Fig. 4), although the range of 3 to $18 \mathrm{mg} \mathrm{m}^{-3}$ was again lower. It appears that peak catchment loads during the 2008 to 2009 monitoring period may have been higher than those applied to the historical model run, particularly for ammonia (which may have been enhanced by overflows from a sewage treatment plant near Yamba). Scenario $2 b$ may be more representative of this period having included 21 years of enhanced loads into Oyster Channel that produced peaks higher than those reported by White (2009) in 14 of those years for nitrate, 3 of those years for ammonia, and 5 of those years for chlorophyll.

Seagrass coverage at the end of the model run was mostly consistent (within a factor of 2) with results from a survey conducted some 16 mo later. The main exception was in Oyster Channel and Wooloweyah 
Table 4. Summary of estuary section responses under the 4 flow conditions identified by Eyre (2000)

\begin{tabular}{|c|c|c|c|}
\hline Medium flow & Flood & Estuary recovery & Dry season \\
\hline \multicolumn{4}{|l|}{ Upper estuary } \\
\hline Low salinity & Freshwater & Freshwater & Low salinity \\
\hline Moderate turbidity & High turbidity & $\begin{array}{l}\text { Moderate turbidity reaching } \\
\text { a local maxima }\end{array}$ & Low turbidity \\
\hline High nutrients & High nutrients & High nutrients & Low nutrients \\
\hline $\begin{array}{l}\text { Small phytoplankton limited } \\
\text { by light and flushing }\end{array}$ & $\begin{array}{l}\text { Small phytoplankton limited } \\
\text { by light and flushing }\end{array}$ & $\begin{array}{l}\text { Small phytoplankton } \\
\text { limited by light }\end{array}$ & $\begin{array}{l}\text { Small phytoplankton shows } \\
\text { a high local maxima }\end{array}$ \\
\hline $\begin{array}{l}\text { Large phytoplankton } \\
\text { dominates chlorophyll } \\
\text { which has a local maxima }\end{array}$ & $\begin{array}{l}\text { Large phytoplankton also } \\
\text { limited by flushing resulting } \\
\text { in low chlorophyll }\end{array}$ & $\begin{array}{l}\text { Large phytoplankton also } \\
\text { light limited but recovering }\end{array}$ & $\begin{array}{l}\text { Large phytoplankton } \\
\text { nutrient limited }\end{array}$ \\
\hline $\begin{array}{l}\text { Macroalgae dominates } \\
\text { phytobenthos }\end{array}$ & $\begin{array}{l}\text { Macroalgae continues } \\
\text { to dominate phytobenthos }\end{array}$ & $\begin{array}{l}\text { Macroalgae declining } \\
\text { after } 3 \mathrm{wk} \text { of low light }\end{array}$ & $\begin{array}{l}\text { Macroalgae dominates } \\
\text { phytobenthos }\end{array}$ \\
\hline $\begin{array}{l}\text { Seagrass limited } \\
\text { by low salinity and light }\end{array}$ & $\begin{array}{l}\text { Seagrass limited } \\
\text { by low salinity and light }\end{array}$ & $\begin{array}{l}\text { Seagrass limited } \\
\text { by low salinity and light }\end{array}$ & $\begin{array}{l}\text { Seagrass limited } \\
\text { by low salinity }\end{array}$ \\
\hline $\begin{array}{l}\text { Zooplankton controlled } \\
\text { by downstream transport }\end{array}$ & $\begin{array}{l}\text { Zooplankton controlled } \\
\text { by downstream transport }\end{array}$ & $\begin{array}{l}\text { Zooplankton controlled } \\
\text { by downstream transport }\end{array}$ & $\begin{array}{l}\text { Zooplankton controlled } \\
\text { by downstream transport }\end{array}$ \\
\hline \multicolumn{4}{|l|}{ Lower estuary } \\
\hline $\begin{array}{l}\text { Salinity increasing } \\
\text { towards the mouth }\end{array}$ & $\begin{array}{l}\text { Freshwater } \\
\text { close to the mouth }\end{array}$ & $\begin{array}{l}\text { Salinity increasing } \\
\text { towards the mouth }\end{array}$ & $\begin{array}{l}\text { High salinity due to limited } \\
\text { freshwater supply }\end{array}$ \\
\hline Low turbidity & High turbidity & $\begin{array}{l}\text { Moderate turbidity } \\
\text { declining towards mouth }\end{array}$ & Low turbidity \\
\hline Moderate nutrients & High nutrients & High nutrients & Low nutrients \\
\hline $\begin{array}{l}\text { Small phytoplankton } \\
\text { limited by flushing }\end{array}$ & $\begin{array}{l}\text { Moderate biomass of small } \\
\text { phytoplankton contributing } \\
\text { to chlorophyll }\end{array}$ & $\begin{array}{l}\text { High biomass of small } \\
\text { phytoplankton decreasing } \\
\text { close to the mouth due } \\
\text { to tidal exchange }\end{array}$ & $\begin{array}{l}\text { Small phytoplankton } \\
\text { dominates chlorophyll }\end{array}$ \\
\hline $\begin{array}{l}\text { Large phytoplankton } \\
\text { nutrient limited }\end{array}$ & $\begin{array}{l}\text { Moderate biomass of large } \\
\text { phytoplankton contributing } \\
\text { to chlorophyll }\end{array}$ & $\begin{array}{l}\text { High biomass of large } \\
\text { phytoplankton decreasing } \\
\text { close to the mouth due } \\
\text { to tidal exchange }\end{array}$ & $\begin{array}{l}\text { Large phytoplankton } \\
\text { strongly nutrient limited }\end{array}$ \\
\hline Low macroalgae biomass & Low macroalgae biomass & Low macroalgae biomass & Low macroalgae biomass \\
\hline $\begin{array}{l}\text { High seagrass biomass } \\
\text { in shallow side-channels }\end{array}$ & $\begin{array}{l}\text { High seagrass biomass } \\
\text { in shallow side-channels }\end{array}$ & $\begin{array}{l}\text { Low seagrass biomass } \\
\text { delayed response to flood }\end{array}$ & $\begin{array}{c}\text { Seagrass recovered } \\
\text { to moderate levels }\end{array}$ \\
\hline $\begin{array}{l}\text { Zooplankton controlled } \\
\text { by downstream transport }\end{array}$ & $\begin{array}{l}\text { Zooplankton controlled } \\
\text { by downstream transport }\end{array}$ & $\begin{array}{l}\text { Zooplankton controlled } \\
\text { by downstream transport }\end{array}$ & $\begin{array}{l}\text { Zooplankton controlled } \\
\text { by downstream transport }\end{array}$ \\
\hline \multicolumn{4}{|l|}{ The Broadwater } \\
\hline Low salinity & Low salinity & Low salinity & Increased salinity \\
\hline Low turbidity & Low to moderate turbidity & Moderate turbidity & Low turbidity \\
\hline Low nutrients & Low to moderate nutrients & $\begin{array}{l}\text { High nutrients lagging } \\
\text { main channel trends }\end{array}$ & Low nutrients \\
\hline $\begin{array}{l}\text { Small phytoplankton } \\
\text { dominates chlorophyll }\end{array}$ & $\begin{array}{l}\text { Small phytoplankton } \\
\text { dominates chlorophyll }\end{array}$ & $\begin{array}{l}\text { Small phytoplankton } \\
\text { dominates chlorophyll }\end{array}$ & $\begin{array}{l}\text { Small phytoplankton } \\
\text { dominates chlorophyll }\end{array}$ \\
\hline $\begin{array}{l}\text { Large phytoplankton } \\
\text { strongly nutrient limited }\end{array}$ & $\begin{array}{l}\text { Large phytoplankton } \\
\text { strongly nutrient limited }\end{array}$ & $\begin{array}{l}\text { Large phytoplankton } \\
\text { increase with nutrients }\end{array}$ & $\begin{array}{l}\text { Large phytoplankton } \\
\text { strongly nutrient limited }\end{array}$ \\
\hline Low macroalgae biomass & Low macroalgae biomass & Low macroalgae biomass & Low macroalgae biomass \\
\hline High seagrass biomass & High seagrass biomass & $\begin{array}{l}\text { Slight decline in seagrass } \\
\text { with increased turbidity }\end{array}$ & $\begin{array}{l}\text { Seagrass increasing under } \\
\text { low turbidity conditions }\end{array}$ \\
\hline $\begin{array}{l}\text { Zooplankton concentrations } \\
\text { follow main channel }\end{array}$ & $\begin{array}{l}\text { Zooplankton concentrations } \\
\text { follow main channel }\end{array}$ & $\begin{array}{l}\text { Zooplankton concentrations } \\
\text { follow main channel }\end{array}$ & $\begin{array}{l}\text { Zooplankton concentrations } \\
\text { follow main channel }\end{array}$ \\
\hline \multicolumn{4}{|c|}{ Wooloweyah Lagoon (and Oyster Channel) } \\
\hline High salinity & High salinity & High salinity & High salinity \\
\hline Low turbidity & Moderate turbidity & Low turbidity & Low turbidity \\
\hline Low nutrients & High nutrients & Moderate nutrients & Moderate nutrients \\
\hline $\begin{array}{l}\text { Small phytoplankton } \\
\text { dominates chlorophyll }\end{array}$ & $\begin{array}{l}\text { Small phytoplankton } \\
\text { dominates chlorophyll }\end{array}$ & $\begin{array}{l}\text { Small phytoplankton } \\
\text { dominates chlorophyll }\end{array}$ & $\begin{array}{l}\text { Small phytoplankton } \\
\text { dominates chlorophyll }\end{array}$ \\
\hline $\begin{array}{l}\text { Large phytoplankton } \\
\text { strongly nutrient limited }\end{array}$ & $\begin{array}{l}\text { Large phytoplankton } \\
\text { limited by zooplankton } \\
\text { grazing }\end{array}$ & $\begin{array}{l}\text { Large phytoplankton } \\
\text { limited by zooplankton } \\
\text { grazing }\end{array}$ & $\begin{array}{l}\text { Large phytoplankton } \\
\text { strongly nutrient limited }\end{array}$ \\
\hline Low macroalgae biomass & Low macroalgae biomass & Low macroalgae biomass & Low macroalgae biomass \\
\hline $\begin{array}{l}\text { Moderate to high seagrass } \\
\text { biomass }\end{array}$ & $\begin{array}{l}\text { Moderate to high seagrass } \\
\text { biomass }\end{array}$ & $\begin{array}{l}\text { Moderate to high seagrass } \\
\text { biomass }\end{array}$ & $\begin{array}{l}\text { Moderate to high seagrass } \\
\text { biomass }\end{array}$ \\
\hline $\begin{array}{l}\text { Zooplankton concentrations } \\
\text { much higher } \\
\text { than main channel }\end{array}$ & $\begin{array}{l}\text { Zooplankton concentrations } \\
\text { much higher } \\
\text { than main channel }\end{array}$ & $\begin{array}{l}\text { Zooplankton concentrations } \\
\text { much higher } \\
\text { than main channel }\end{array}$ & $\begin{array}{l}\text { Zooplankton concentrations } \\
\text { much higher } \\
\text { than main channel }\end{array}$ \\
\hline
\end{tabular}


Lagoon where the model predicted high seagrass coverage (30 to $40 \%$ ) where negligible coverage was observed. While the model suggests that these environments are highly favourable to seagrass, other factors such as high levels of benthic disturbance by prawn trawling or removal of nutrients by riparian vegetation may be limiting (this is also explored in the scenario results below).

Unfortunately there were no in situ measurements of bottom sediment processes in the Clarence River Estuary available for comparison with the model outputs. However, denitrification has been studied within some of the smaller estuaries of northern NSW (Eyre \& Ferguson 2005, 2006) and other parts of eastern Australia (Eyre \& Ferguson 2009, Ferguson \& Eyre 2010). Consistent with these measurements, the model produced a wide range of nitrification efficiencies (5 to $100 \%$ ) that increased with seasonal water temperature and distance upstream. The model average was $32 \%$ for the main channel and $25 \%$ for the entire system, which is within the range of Australian coastal systems included in the meta-analysis of Eyre \& Ferguson (2009) and comparable to estimates from the nearby Brunswick Estuary of $22 \%$ (Eyre \& Ferguson 2005) and $39 \%$ (Eyre \& Ferguson 2009). In the absence of local measurements, these comparisons at least suggest that the nutrient cycling in the sediment component of the model is plausible.

Eyre (2000) identified 4 flow and nutrient cycling phases based on observations of the Clarence River Estuary and other subtropical estuaries in eastern Australia. Fig. 4 compares these phases with corresponding model responses, which are described further in Table 4. A number of key features of the responses emerge from this analysis:

(1) During the wet season, the upper estuary typically remained quite fresh (Fig. 4a-c [i]) and catchment inputs supported relatively high turbidity (Fig. 4a-c [ii]) and nutrient concentrations (Fig. 4a-c [iii]), which favoured larger phytoplankton (Fig. 4a-c [vi]). This reversed in the dry season when low turbidity and nutrient concentrations favoured small phytoplankton and rapid recycling of nutrients (Fig. 4d [i-v]). Zooplankton biomasses responded more gradually to the flow conditions and were strongly dependent on the concentrations that entered the top of the estuary (Fig. 4 [viii-ix]).

(2) Compared to the upper estuary, the lower estuary was characterised by higher salinities and lower turbidity and nutrient concentrations due to processes such as settling, nutrient uptake and dilution by oceanic water (Fig. 4 [i-iv]). These conditions were most favourable to small phytoplankton (Fig. 4 [v]). However, both small and large phytoplankton in the lower estuary benefited from flood events (Fig. 4b [v-vii]).

(3) Because parts of the main channel were quite deep (Fig. 1), phytobenthos tended to be concentrated in the upper reaches and shallower sidechannels. Macroalgae dominated in the upper estuary and seagrass in the lower estuary (Fig. 4 [x-xi]). In both instances, floods reduced phytobenthos biomass by initiating prolonged periods of light deprivation that persisted throughout the estuary recovery phase (Fig. 4c [x-xi]).

(4) The 2 large coastal lagoons provided more stable environments than the channels. Turbidity and nutrient concentrations remained relatively low (Fig. 4 [ii-iv]) and small phytoplankton dominated over the nutrient limited large phytoplankton (Fig. 4 [v-vi]). High concentrations of small phytoplankton and the relatively long residence times of Wooloweyah Lagoon (11 to $20 \mathrm{~d}$; Lancaster 1990) allowed zooplankton concentrations to increase far above the levels found elsewhere in the system (Fig. 4 [viii-ix]). The lagoons, particularly the shallower Broadwater, also provided conditions favourable to seagrass (Fig. 4 [xi]).

In summary, the model responses were consistent with historical data, as well as the conceptual models proposed by Eyre (2000) for a range of flow conditions (Fig. 4 [xii]). This is not too surprising given that Eyre's conceptual model and the calibration of CREAM were based on the same set of observations. However, further analysis of CREAM outputs will now allow us to extrapolate to a broader range of conditions and explore longer-term trends in the system.

\section{Historical trends}

The seasonal cycle of autumn flooding followed by a winter dry season was evident throughout much of the last half century, albeit with significant variations in intensity and timing (Fig. 5a). Wetter periods with more regular flooding over 1 to 3 years typically occurred once or twice per decade (e.g. early 1960s and late 1980s), and extended dry periods without floods also occurred (e.g. 1992 to 1994).

\section{Main channel}

The model response in the main channel to each event followed the cycle of flood, recovery and dry 


\section{Year}
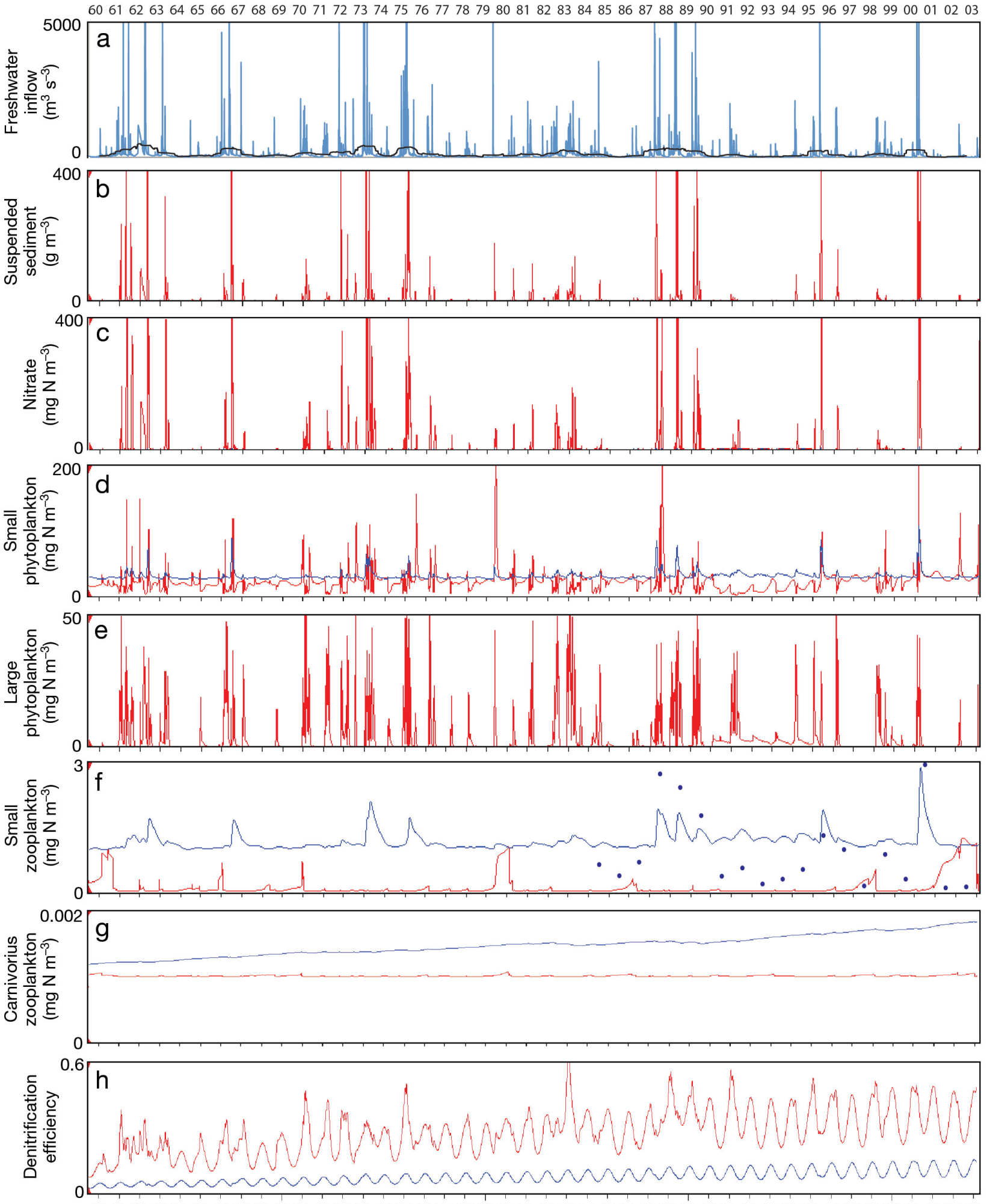

6061626364656667686970717273747576777879808182838485868788899091929394959697989900010203

— Mid-estuary (Maclean) — Lagoon (Wooloweyah) • Relative prawn catch (Ocean Prawn Trawl)

Fig. 5. Time-series of model outputs from the main channel at Maclean (red lines) and Wooloweyah Lagoon (blue lines): (a) Freshwater discharge at the top of the estuary (blue = daily data, black $=365 \mathrm{~d}$ running average); (b) suspended sediment concentration (lagoon values not visible on this scale); (c) nitrate (lagoon values not visible on this scale); (d) small phytoplankton; (e) large phytoplankton (lagoon values not visible on this scale); (f) small zooplankton and published data on relative annual prawn catches from the coastal area around the estuary mouth $\left(29^{\circ} \mathrm{S}\right.$ to $\left.30^{\circ} \mathrm{S}\right)$ (Ives et al. 2009); (g) carnivorous zooplankton; and $(\mathrm{h})$ benthic denitrification efficiency 
season identified in the 1996 data (Eyre 1998b) and simulations (Fig. 4), with large peaks in suspended sediments, nutrients and phytoplankton mirroring the freshwater forcing over the $44 \mathrm{yr}$ of the simulation (Fig. 5b-e).

During flood events, flushing timescales within the estuary were less than a day so that phytoplankton, with growth timescales of 0.8 to $4 \mathrm{~d}$ (Table 1), tended to be flushed out of the upper estuary (Fig. 4b [v-vii]). Following each peak, flushing timescales returned to more typical values ( $>20$ d) allowing plankton and chlorophyll concentrations to recover (Fig. 4c [v-vii]). However, large phytoplankton then declined over 1 to 2 mo as the available nutrients were consumed (Figs. 4d [vi] \& 5e) and only on rare occasions were they sustained throughout the year by more regular river discharge events (e.g. 1992 to 1994). Small phytoplankton in the main channel also responded to discharge events, but tended to be more persistent between events as they utilised recycled nutrients (Figs. 4d [v] \& 5d).

Small zooplankton populations in the main channel responded to extended periods of elevated small phytoplankton concentrations (more than $1 \mathrm{yr}$ as in 1980-1981 and 2002-2003, cf. Fig. 5d,f). However, the response of their carnivorous zooplankton predators was more limited, even during these periods of abundant prey (Fig. 5g). This can be explained in terms of their low growth rate, which ensured that they were flushed through the system before significant growth could occur.

Plankton and benthos mortality contributed to a gradual accumulation of detritus in the sediments and a corresponding increase in the bacterial biomass (not shown). Over this period, the annual mean denitrification efficiency increased from around 20 to $35 \%$ at mid-estuary, typically peaking at $50 \%$ during the wet season (Fig. 5h). There was also a significant gradient along the estuary, increasing from an annual average of $15 \%$ near the mouth to $85 \%$ in the upper estuary. Because denitrification varied with a fairly regular season cycle (Fig. 5h), the fraction of the total estuarine DIN load removed by denitrification each month varied from insignificant levels during flood periods $(<1 \%)$ to more than 20 times during drought periods. However, the average over the modelling period was approximately $13 \%$.

\section{Coastal lagoon}

Wooloweyah Lagoon evolved differently to the main channel due to factors such as lower inputs of suspended sediments and nutrients, and lower flushing rates. One consequence was that large phytoplankton tended to be strongly nitrogen limited. However, remineralised nutrients and long residence times allowed small phytoplankton biomass to expand until balanced by small zooplankton grazing, only escaping briefly from this equilibrium state during large flood events (Fig. 5d). It is interesting to note that recorded prawn catches (Ives et al. 2009) co-vary with the modelled small zooplankton in Wooloweyah Lagoon $\left(r^{2}=0.78\right.$, Fig. $\left.5 f\right)$, the underlying driver in both cases being river discharges (Fig. 5a).

The persistence of the small zooplankton biomass (Fig. 5f) combined with more seasonal detritus (not shown) helped support relatively large populations of carnivorous zooplankton (Fig. 5g). While carnivorous zooplankton in the main channel showed little change over the $44 \mathrm{yr}$ simulation period, those in Wooloweyah Lagoon increased by almost $40 \%$ (Fig. 5g). This was supported by underlying growth in small zooplankton and water column detritus concentrations, ultimately driven by increases in nutrient loads associated with changing land-use (the largest percentage increase occurred in the Wooloweyah subcatchment: Table S2 in the supplement).

Denitrification efficiencies in the lagoon followed a regular seasonal cycle and reached mean annual values of around $14 \%$. They were similar to those near the mouth of the estuary (not shown), but lower than in mid-estuary by a factor of around 3 (Fig. 5h). Even at these relatively low efficiencies, denitrification removed an average of $25 \%$ of the DIN load arriving from the local sub-catchment.

\section{Long-term system-wide trends}

Pelagic components of the Clarence River Estuary ecosystem responded strongly to freshwater inputs and thereby experienced high levels of interannual variability throughout the modelling period (Fig. 6). However, correlations between annual mean biomasses and flow were low $\left(r^{2}<0.07\right)$ indicating that a range of processes contributed to the highly nonlinear responses (Swaney et al. 2008). The 1980s was generally a period of enhanced flow, nutrients and phytoplankton, with the trend reversing over the 1990s (Fig. 6a-d). Small zooplankton concentrations were more stable, with occasional stronger years following periods of low flow and reduced flushing losses (e.g. 1970 and 1980 in Fig. 6e). Carnivorous zooplankton was very stable at levels largely de- 


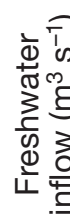
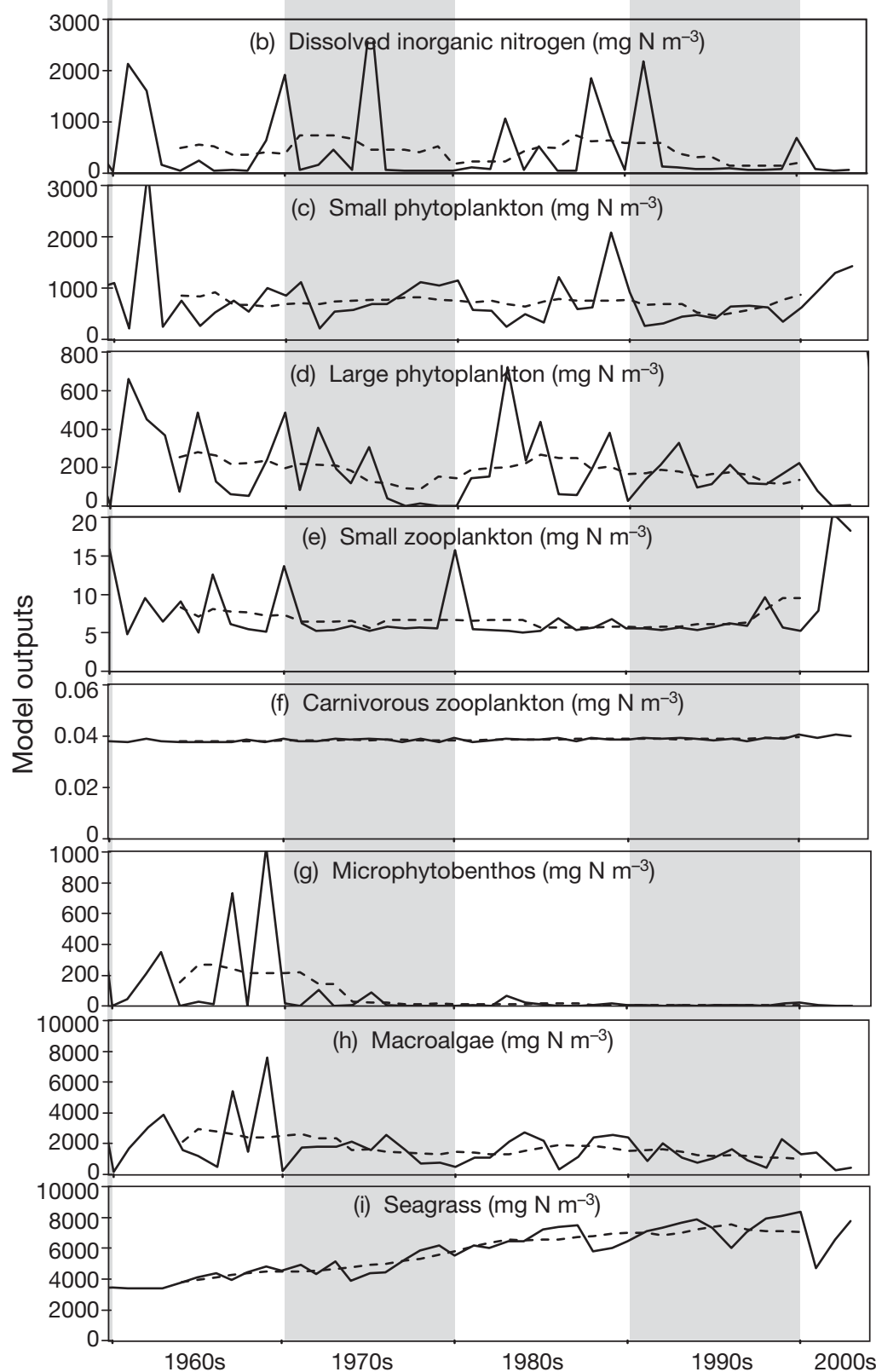

Fig. 6. (a) Freshwater discharge into the upper estuary represented as both a 365 d running average and a 9 yr running average. (b-i) Model outputs averaged annually and spatially over the entire system (solid lines) and corresponding 9 yr running averages (dashed lines)

termined by upstream concentrations (Fig. 6f). The slight upward trend throughout the modelling period was almost entirely attributable to the previously identified growth in Wooloweyah Lagoon.
Both microphytobenthos and macroalgae responded positively to periods of enhanced river discharge (cf. Fig. $6 a, g, h ; r^{2}=0.06$ and 0.30 respectively for annual averages), although microphytobenthos biomass remained low after the 1960s. Seagrass was negatively correlated with river discharge $\left(\mathrm{r}^{2}=\right.$ 0.22 for annual averages) due mainly to the influence of sediments on light, with epiphytic fouling (at high nutrient concentrations) being far less significant. Seagrass increased by around $60 \%$ from the 1960 s to the 1990s (Fig. 6i). Much of this growth occurred in Wooloweyah Lagoon, fuelled by the remineralisation of accumulating detritus in the bottom sediments. However, this response is not consistent with historical downward trends, suggesting that other factors may influence seagrasses in the lagoon. This issue will be explored further in the scenarios below.

\section{Alternative scenarios}

Land-use and urbanisation

The scenario results indicated that realistic changes in agricultural practices, land-uses, and urbanisation (scenarios $1 \mathrm{a}, \mathrm{b}$ and $2 \mathrm{a}, \mathrm{b}$ in Table 2) had very little impact on the estuary as a whole (Fig. 7). Impacts were minor throughout the various channels and The Broadwater, even for urban development on the main channel at Maclean. However, with its lower historical loads and flushing rates, Wooloweyah Lagoon again proved to be more sensitive, particularly to urban development around Yamba. The associated increase in average DIN $(\sim 11 \%)$ reduced periods of nutrient limitation and supported substantial increases in the average biomass of all plankton groups (45 to $98 \%$ ) in the lagoon (Fig. 7). While denitrification almost doubled (with a modest increase in denitrification efficiency from 14 to $17 \%$ ), this offset only a small proportion of the additional nutrient load. During 1981-1982, seagrasses in the lagoon experienced a temporary decline $(\sim 20 \%)$ due to the higher suspended sediment concentrations associated with the construction phase of the Yamba development (not shown). However, as sediments returned to historical concen- 


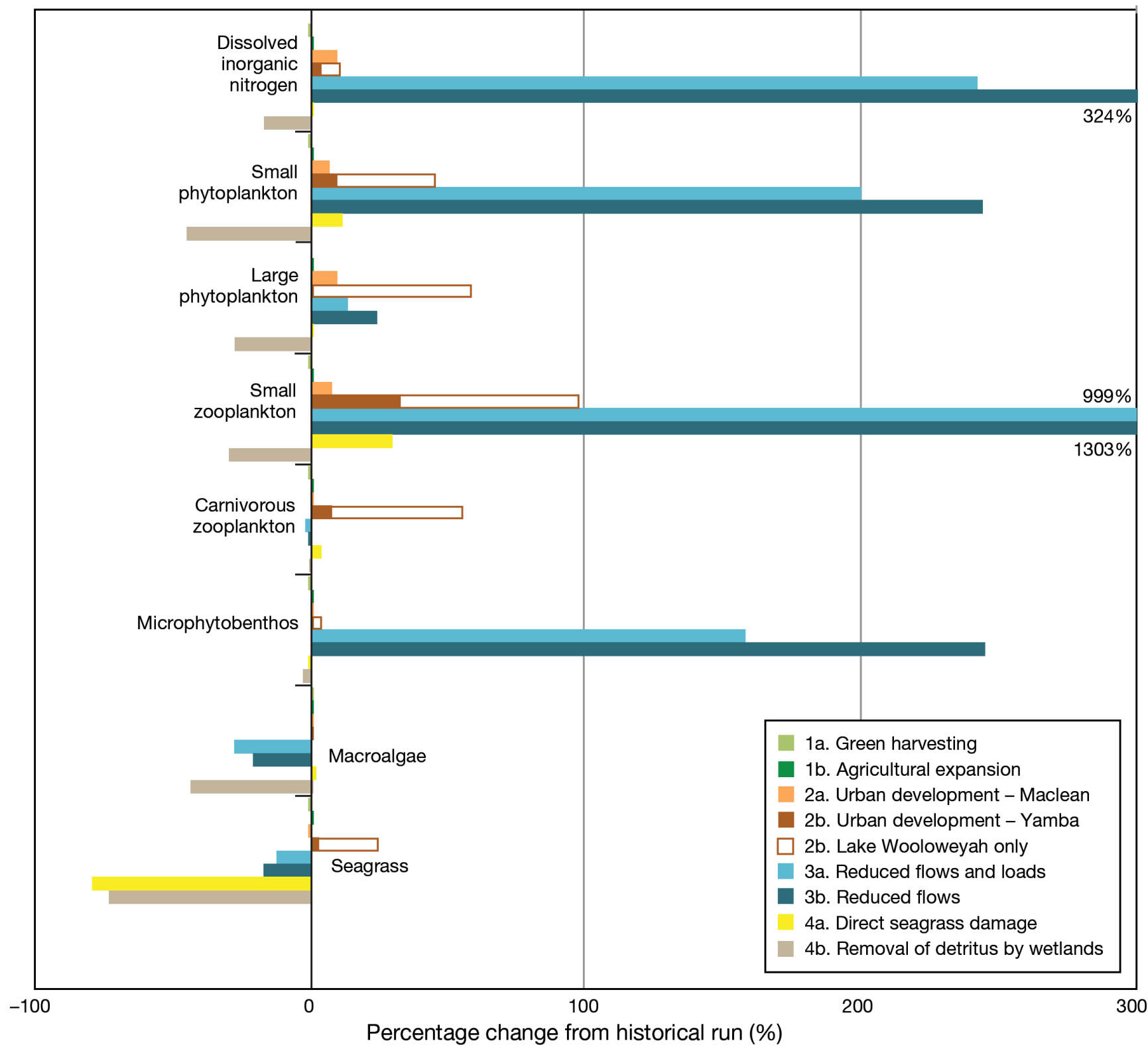

Fig. 7. Percentage change in biomasses of functional groups for each scenario relative to the historical run (averaged from 1980 to 2003). The filled bars are totals over the system, while unfilled bars are for Wooloweyah Lagoon with urban development at Yamba

trations, the ongoing nutrient loads from the development reversed this trend and resulted in a net increase in seagrass biomass (Fig. 7).

\section{River discharge}

Moderate reductions in freshwater discharges from the upper catchment (reduced rainfall or increased extraction) combined with reduced exchanges throughout the system (enhanced siltation, scenarios 3a,b in Table 2) caused a large increase in estuarine nutrients (Fig. 7) and approximately doubled the concentrations of labile and refractory detritus (not shown). The corresponding increase in denitrification was minor in the upper estuary $(<20 \%)$, but grew to a factor of 7 from mid-estuary (Maclean) to the mouth. There was also a marked increase in denitrification efficiency in the lower estuary, with high values (>85\%) extending downstream almost to the mouth.

These changes favoured microphytobenthos over macroalgae and seagrass, which both declined. The 
biomasses of small phytoplankton responded roughly in proportion to the nutrient increase, while the more limited response of large phytoplankton suggests that nutrients continued to be limiting for much of the time. A disproportionate enhancement in the biomass of small zooplankton (Fig. 7) reflected the increased availability of food (small phytoplankton and detritus) and longer residency times in the estuary. However, the absence of any significant response in carnivorous zooplankton, despite increased abundance of prey, suggests that their biomass continued to be limited by flushing.

The response of Wooloweyah Lagoon to a drop in river discharge and tidal exchanges was again different than for other parts of the estuary. Denitrification in bottom sediments increased by around $40 \%$ and average denitification efficiency rose from 14 to $18 \%$. Given the accompanying $15 \%$ reduction in flushing, denitrificiation clearly played a larger role in removal of nitrogen from the lagoon under these scenarios. However, there was very little net change in water column nitrate concentrations and any short-term increases in small phytoplankton and small zooplankton (up to $200 \%$ during major flow events) were largely due to exchanges with the main channel (as evidenced by gradients in their concentration along the adjoining Oyster Channel - not shown). With no underlying increase in small zooplankton or water column detritus, the gradual increase in large zooplankton biomass observed in the historical run (Fig. 5g) also disappeared.

\section{Habitat change}

Changes within the habitat groups (scenarios $4 \mathrm{a}, \mathrm{b}$ in Table 2) could also have a significant influence on the broader system. Increased mortality of seagrass (potentially arising through mechanical disturbance or increases in contaminants) resulted in an $80 \%$ reduction in biomass (Fig. 7), a large proportion of which occurred in Lake Wooloweyah. While this resulted in only a small increase in average nutrients $(<2 \%)$, the reduced utilisation by seagrass through periods of strong nitrogen limitation allowed a disproportionately large increase in small phytoplankton $(12 \%)$ and their small zooplankton grazers $(30 \%)$.

Allowing for efficient removal of detritus by riparian wetlands reduced the rate of remineralisation to insignificant levels. The subsequent fall in nitrogen concentrations $(17 \%)$ cascaded through to large and small phytoplankton and small zooplankton (Fig. 7).
There was also a major impact on macroalgae and seagrass (reductions of 45 and $74 \%$, respectively) suggesting that there is potential for strong competition between riparian and aquatic vegetation for available nutrients in this system.

Conceptual summary and qualitative analysis

The long-term responses identified by the scenarios described above can be summarised within a simple qualitative model composed of the main system components and their interactions (Fig. 8). The estuary channels and Wooloweyah Lagoon could be distinguished by removing one or other of the river discharge interactions shown in the model digraph. Identification of these 2 distinct model structures also had the advantage that it removed opposing feedbacks from the system (i.e. river discharge having both a direct positive effect and an indirect negative effect on nutrients) and thereby provided unambiguous predictions in both cases.

Qualitative (loop) analyses of the 2 model structures (Appendix 1) indicated that the responses to sustained changes in land-use or habitat coverage

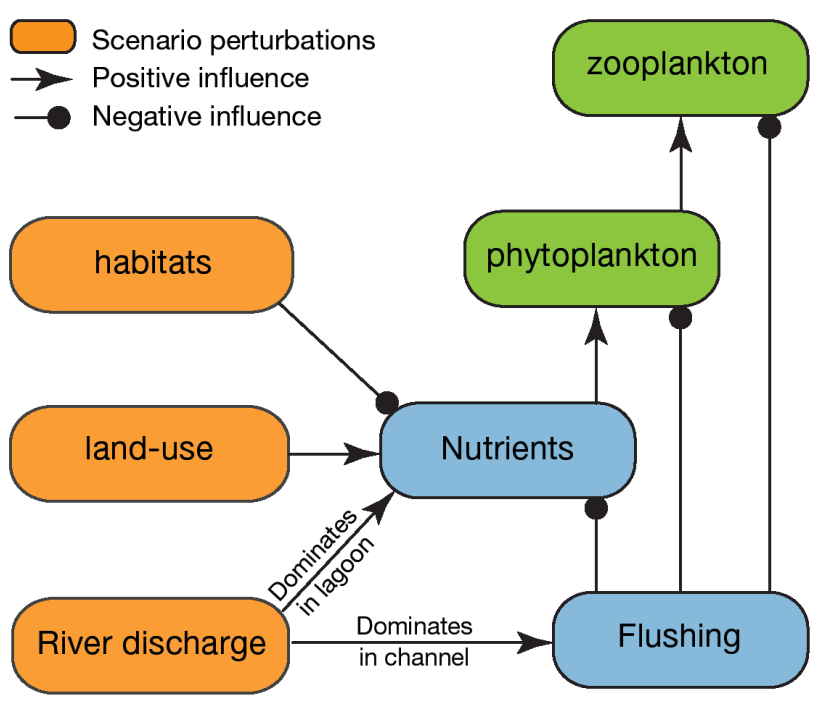

Fig. 8. Signed digraph of the simplest model that shows the same (qualitative) responses as CREAM. Lines ending in an arrow indicate a positive effect of one variable on another and lines ending in a circle indicate a negative effect of one variable on another. This system is only stable if each component also includes a negative self-effect (i.e. densitydependence) that is not shown explicitly here. Models for the estuary channels and Wooloweyah Lagoon can be treated separately by removing one or other of the river discharge interactions (this also removes opposing feedbacks in the system and thereby provides unambiguous predictions of the model responses) 
were the same in both the estuarine channels and Wooloweyah Lagoon, although the CREAM results indicated that the quantitative response was much stronger in the lagoon. The responses to river discharge differed qualitatively, with nutrients, phytoplankton and zooplankton increasing with river discharge in the lagoon (due to nutrient influx) and decreasing with river discharge in the channels (due to flushing). In these instances, CREAM results showed a weak response in the lagoon and a strong response in the channel.

\section{DISCUSSION}

Models such as CREAM can provide new insights into estuarine responses and contribute to their improved management. With the inclusion of realistic physical transports and chemical and biological transformations, they provide strong constraints on the range of feasible responses through their water and nutrient budgets. This approach has successfully reproduced the flow regimes identified by observational studies (Eyre 1998b, Eyre 2000) and provided a flexible modelling platform to explore and understand long-term estuarine responses to natural and human induced change. The model results support our original hypotheses that sustained changes in river discharge can have a major impact on the ecology of subtropical estuaries and that ecological responses can differ markedly between the environments of estuary channels and coastal lagoons. The implications for estuarine management priorities are discussed here.

\section{Model uncertainties}

Biogeochemical estuary models are required to integrate a large number of parameterised processes, and in systems like the Clarence River Estuary with limited in situ data, there are significant uncertainties in the parameters and the model structure. Care is therefore required in the interpretation and application of the model results. As a rule, relative systemwide responses to changes in broad-scale forcing (Fig. 7) are likely to be more robust than quantitative predictions for specific localities.

There are clearly uncertainties in all aspects of the model and some components or processes have only been represented in a rudimentary way. In these instances, the results provide guidance for prioritising future model improvements. For example, while the coastal catchment model was relatively simple, estimated nutrient inputs had little influence on the estuarine channels. On the other hand, there may be significant value in the development of more sophisticated catchment models for regions surrounding coastal lagoons, where nutrient inputs are more criti$\mathrm{cal}$. In the case of the Wooloweyah Lagoon, measurements suggest that recent ammonia inputs may be nearer those used in the urbanisation scenario than the historical scenario, probably due to occasional overflow from wetlands used by a local sewage treatment plant to recycle treated water (White 2009).

Given that model validation was mostly limited to the water column, there are significant uncertainties associated with processes in the bottom sediments. The seasonal range and downstream distribution of model denitrification efficiencies were consistent with measurements in other Australian estuaries (Eyre \& Ferguson 2009, Ferguson \& Eyre 2010) and elsewhere (e.g. Trimmer et al. 1998), and its contribution to the removal of the DIN ( 13\% of the load) is very plausible. However, in situ measurements in the Clarence River Estuary will be required to properly test these hypotheses and improve representation of sediment processes in the model.

Another significant source of model uncertainty was the influence of riparian vegetation, which can capture detritus during tidal exchanges and eventually export it to the atmosphere through denitrification within wetland sediments. Denitrification rates within mangrove forests tend to be much lower than those for saltmarshes (Rivera-Monroy \& Twilley 1996, Valiela \& Cole 2002) and limited measurements within Australian mangroves have shown them to be net tidal exporters of nitrogen (Boto \& Robertson 1990). Saltmarshes in Australia tend to be less productive than those in other parts of the world, with less frequent tidal inundation (Saintilan \& Williams 1999), and are typically well-oxygenated with limited denitrification (Laegdsgaard 2006). It has therefore been suggested that there is little net exchange of nitrogen between Australian saltmarshes and adjacent waterways, although they may significantly moderate catchment inputs as observed in other regions (Valiela \& Cole 2002). The scenarios covered the extremes of no removal of detritus by riparian vegetation (historical run) and near complete removal (scenario $4 \mathrm{~b}$ ), with significant differences evident in most of the biological components (Fig. 7). This points to the need for inclusion of more detailed models of wetland processes, particularly around coastal lagoons and other slowly flushing systems. 


\section{Comparable systems}

Estuaries have been impacted by agricultural, urban and industrial development throughout many of the wet subtropical regions of the world. However, the characteristics and responses of these systems vary significantly (Cloern 2001), and detailed studies are still limited to a relatively few regions, such as eastern Australia (Eyre 1997, 1998a, 2000, Roy et al. 2001) and the northern Gulf of Mexico (Bianchi et al. 1999, Murrell et al. 2007, Lehrter 2008).

The Clarence River Estuary is significantly larger than other subtropical estuaries in eastern Australia, with water surface area a factor of at least 6 larger and flushing times more than 50\% longer (Eyre 2000). However, its characteristics appear to coincide more closely with some of the northern Gulf of Mexico systems. For example, the catchment for Escambia Bay (which feeds into Pensacola Bay) is about half the size of the Clarence River Estuary catchment, but includes areas of pasture, cropping and urbanisation comparable to the latter. The areas of the estuaries and mean depths are within $15 \%$ of each other, and the Clarence River average discharge is only $30 \%$ less than the Escambia River. Most of the chlorophyll a measurements reported from the Escambia Bay by Murrell et al. (2007) were within the range of 1 to $10 \mathrm{mg} \mathrm{m}^{-3}$ obtained for the main channel of the Clarence Estuary (Eyre 1998b, Fig. 3), and all were within the range observed for the system as a whole (including Lake Wooloweyah, White 2009). More importantly, both systems varied strongly in response to river discharge, with chlorophyll declining during flood events then peaking during the post-flood recovery phase (Figs. $3 \& 4$ ). This suggests that the ecological responses of the 2 estuaries may be broadly comparable and, more generally, that our model results might provide a basis for developing new hypotheses about other subtropical systems.

\section{Contrasting responses of estuarine channels and coastal lagoons}

The model results suggest that, even within a single estuarine system, the ecology of coastal lagoons (with relatively low flushing rates) is very different from that of estuary channels. The natural conditions in the lagoon were generally more favourable to seagrass, with riparian wetlands and bottom sediments also potentially playing large roles in nutrient cycling. While most of the system was insensitive to additional nutrient inputs, Wooloweyah Lagoon showed a marked increase in all the plankton groups and seagrass (Fig. 7). The increase in phytoplankton is consistent with the typical succession of aquatic plants under increasing nutrient load (e.g. Viaroli et al. 2008), although the absence of any decline in denitrification efficiency or seagrass biomass indicates that the model system had not yet reached the unstable eutrophic regime observed in many other coastal lagoons under nutrient stress (e.g. Rysgaard et al. 1996, Webster \& Harris 2004).

Differences in flushing rates also had a significant influence on the plankton groups. Being less limited by nutrients than larger phytoplankton, small phytoplankton concentrations were often constrained by flushing through the main channel (to levels below those in the lagoons) and bloom conditions were restricted to the lower estuary (Fig. 4). Zooplankton concentrations were even more strongly constrained by residence time in the main channel, while in Wooloweyah Lagoon they were only limited by the availability of phytoplankton (Fig. 5). While control of phytoplankton and zooplankton by flushing has been recognised in many estuaries (Basu \& Pick 1996, Lucas et al. 1999, Borsuk et al. 2004, Lehrter 2008), the Clarence River Estuary system exhibits both high and low flushing regimes that interact through a single interconnected system.

The contrast in the dynamics of estuary channels and coastal lagoons also has potential implications for the design of monitoring programs. The temporal variability associated with river discharges into tropical and subtropical estuarine channels is likely to confound many traditional monitoring strategies (Fig. 3). However, in systems such as the Clarence River Estuary, lagoons provide a more stable environment where statistically valid trends might be identified from a realistic monitoring program (e.g. monthly). Similar arguments can be made for including zooplankton groups (with longer turnover timescales) as part of estuarine monitoring strategies.

\section{Management implications}

The model results suggest that a single water quality management regime may not be suitable for both coastal lagoons and estuary channels. With lower flushing rates, coastal lagoons are much more sensitive to nutrient inputs. This implies the need for careful management of their surrounding catchments, particularly as coastal lagoons throughout the world come under increasing pressure from urbanisation (e.g. Figueiredo da Silva et al. 2002, Faulkner 2004, 
Lee et al. 2006). Being less sensitive than other parts of the estuary to river discharge rates, lagoons may also provide a refuge from climate-induced changes for some species, further supporting the case for enhanced conservation status.

With high flushing rates and relatively high nutrient loads from the upper catchment, estuary channels are less sensitive to changes in urban development, landuse and agricultural practices in the lower catchment. However, the model results suggest that they can be highly sensitive to changes in river discharge. Sustained increases in extraction of freshwater or reductions in rainfall result in a more eutrophic state with higher plankton production, increased detritus loads and declines in habitat groups such as macroalgae and seagrass. In regions with increasing human populations and decreasing freshwater resources (such as in subtropical eastern Australia) more detailed understanding of these processes will be key to managing the trade-offs between water allocations and estuarine water quality and habitat health.

Any increases in estuarine plankton production may be associated with increased fish production and/or changes in the structure of fish communities. From a fisheries perspective, the Clarence River Estuary is one of the most important coastal systems in Australia, supporting major commercial fisheries (Glaister 1978a, Ives et al. 2009) and recreational fisheries (Reid \& Montgomery 2005). Given the conditions predicted by the model for Wooloweyah Lagoon (enhanced detritus, zooplankton and seagrass), it is not surprising that it currently supports a large proportion of the valuable Clarence River Estuary prawn fishery. The model scenarios suggest that additional urban development may increase the overall productivity of the Wooloweyah Lagoon. However, this needs to be traded off against deterioration in water quality and any loss of riparian or benthic habitats. These tradeoffs are now being explored using an expanded version of the CREAM model that includes other key invertebrate groups, as well as fish, birds and mammals.

School prawns migrate from Wooloweyah Lagoon onto the inner shelf (Glaister 1978b), and ocean trawl catches generally increase in years of high river discharge (Glaister 1978a, Ives et al. 2009). While this may be explained in terms of enhanced flushing of estuarine prawns onto the shelf, the high correlation of catch with modelled small zooplankton in Wooloweyah Lagoon (Fig. 5) suggests that availability of food may also play a role. In this context, the model explains $78 \%$ of the variability in annual prawn catch (Fig. 5), which is much higher than the correlation between river discharge and any of the annually aver- aged biomasses in the model. This value also compares very favourably to correlations achieved in most empirical regression models that have been applied to coastal and estuarine fisheries (e.g. Glaister 1978a, Cyrus \& Blaber 1992, Ansari et al. 2003, Ives et al. 2009). The use of our dynamical model in this context is attractive in that its validity potentially extends beyond the range of available empirical data. However, broader application of models such as this one for management purposes is likely to be limited in the short term by their high parameterisation requirements compared to traditional empirical models.

Acknowledgements. This research was supported by CSIRO and NSW Industry and Investment (Primary Industries). Our thanks to T. Walford for collation and mapping of available land-use data and to R. Smith for plotting the model grid structure. Thanks also to P. Gibbs, B. Creese, K. Astles, K. Sainsbury and S. Kennelly for their advice and support throughout the study.

\section{LITERATURE CITED}

Alpine A, Cloern J (1992) Trophic interactions and direct physical effects control phytoplankton biomass and production in an estuary. Limnol Oceanogr 37:946-955

Ansari ZA, Sreepada RA, Dalal SG, Ingole BS, Chatterji A (2003) Environmental influences on the trawl catches in a bay-estuarine system of Goa, west coast of India. Estuar Coast Shelf Sci 56:503-515

Baginska B, Lu Y, Mawer D, Pritchard T (2004) Linking land use decisions to nutrient exports. Prepared for the Comprehensive Coastal Assessment (DoP) by the Department of Environment and Conservation, Sydney

Basu BK, Pick FR (1996) Factors regulating phytoplankton and zooplankton biomass in temperate rivers. Limnol Oceanogr 41:1572-1577

Berelson WM, Heggie D, Longmore A, Kilgore T, Nickson G, Skyring G (1998) Benthic nutrient recycling in Port Phillip Bay, Australia. Estuar Coast Shelf Sci 46:917-934

Bianchi TS, Pennock JR, Twilley RR (eds) (1999) Biogeochemistry of Gulf of Mexico estuaries, 1st edn. John Wiley \& Sons, New York

Bohren CF, Huffman DR (1983) Absorption and scattering of light by small particles. John Wiley \& Sons, New York

Bormans M, Condie SA (1998) Modelling the distribution of Anabaena and Melosira in a stratified weir pool. Hydrobiologia 364:3-13

> Borsuk ME, Stow CA, Reckhow KH (2004) Confounding effects of flow on estuarine response to nitrogen loading. J Environ Eng 130:605-614

> Boto KG, Robertson AI (1990) The relationship between nitrogen fixation and tidal exports of nitrogen in a tropical mangrove system. Estuar Coast Shelf Sci 31:531-540

Brodie JE, Mitchell AM (2005) Nutrients in Australian tropical rivers: changes with agricultural development and implications for receiving environments. Mar Freshw Res 56:279-302

Brown JH, Gillooly JF, Allen AP, Savage VM, West GB (2004) Towards a metabolic theory of ecology. Ecology 85:1771-1789 
Bureau of Meteorology (2011). www.bom.gov.au/climate/ change/aus_cvac.shtml

- Chen B, Liu H (2010) Relationships between phytoplankton growth and cell size in surface oceans: Interactive effects of temperature, nutrients, and grazing. Limnol Oceanogr 55:965-972

> Cloern JE (2001) Our evolving conceptual model of the coastal eutrophication problem. Mar Ecol Prog Ser 210: 223-253

> Condie SA (1999) Settling regimes for non-motile particles in stratified waters. Deep-Sea Res I 46:681-699

> Condie SA, Bormans M (1997) The influence of density stratification on particle settling, dispersion and population growth. J Theor Biol 187:65-75

> Cyrus DP, Blaber SJM (1992) Turbidity and salinity in a tropical northern Australian estuary and their influence on fish distribution. Estuar Coast Shelf Sci 35:545-563

> Dambacher JM, Li HW, Rossignol PA (2003) Qualitative predictions in model ecosystems. Ecol Model 161:79-93

> Drewry JJ, Newham LTH, Greene RSB, Jakeman AJ, Croke BFW (2006) A review of nitrogen and phosphorus export to waterways: context for catchment modelling. Mar Freshw Res 57:757-774

Eyre B (1997) Water quality in an episodically flushed subtropical Australian estuary: a 50 year perspective. Mar Chem 59:177-187

Eyre B (1998a) Transport, retention and transformation of material in Australian estuaries. Estuaries 21:540-551

Eyre B (1998b) Water quality in the Clarence Estuary. Centre for Coastal Management, Southern Cross University, Lismore

Eyre BD (2000) Regional evaluation of nutrient transformation and phytoplankton growth in nine river-dominated sub-tropical east Australian estuaries. Mar Ecol Prog Ser 205:61-83

- Eyre BD, Ferguson AJP (2002) Comparison of carbon production and decomposition, benthic nutrient fluxes and denitrification in seagrass, phytoplankton, benthic microalgae- and macroalgae-dominated warm-temperate Australian lagoons. Mar Ecol Prog Ser 229:43-59

> Eyre BD, Ferguson AJP (2005) Benthic metabolism and nitrogen cycling in a subtropical east Australian estuary (Brunswick): temporal variability and controlling factors. Limnol Oceanogr 50:81-96

Eyre BD, Ferguson AJP (2006) Impact of a flood event on benthic and pelagic coupling in a sub-tropical east Australian estuary (Brunswick). Estuar Coast Shelf Sci 66: 111-122

Eyre BD, Ferguson AJP (2009) Denitrification efficiency for defining critical loads of carbon in shallow coastal ecosystems. Hydrobiologia 629:137-146

Faulkner S (2004) Urbanization impacts on the structure and function of forested wetlands. Urban Ecosyst 7:89-106

Ferguson AJP, Eyre BD (2010) Carbon and nitrogen cycling in a shallow productive sub-tropical coastal embayment (western Morton Bay, Australia). Ecosystems 13:1127-1144

Figueiredo da Silva J, Duck RW, Hopkins TS, Rodrigues M (2002) Evaluation of the nutrient inputs to a coastal lagoon: the case of the Ria de Aveiro, Portugal. Hydrobiologia 475-476:379-385

- Fulton EA (2010) Approaches to end-to-end ecosystem models. J Mar Syst 81:171-183

> Fulton EA, Smith ADM, Johnson CR (2003) Effect of complexity on marine ecosystem models. Mar Ecol Prog Ser 253:1-16
Fulton EA, Parslow JS, Smith ADM, Johnson CR (2004) Biogeochemical marine ecosystem models II: the effect of physiological detail on model performance. Ecol Model 173:371-406

> Fulton EA, Smith ADM, Punt AE (2005) Which ecological indicators can robustly detect effects of fishing? ICES J Mar Sci 62:540-551

Fulton EA, Smith ADM, Smith DC (2007) Alternative management strategies for southeastern Australian Commonwealth fisheries: Stage 2: Quantitative Management Strategy Evaluation. Report to the Australian Fisheries Management Authority and the Fisheries Research and Development Corporation. CSIRO Marine and Atmospheric Research, Hobart

Gillanders BM, Kingsford MJ (2002) Impact of changes in flow of freshwater on estuarine and open coastal habitats and the associated organisms. Oceanogr Mar Biol Annu Rev 40:233-309

Glaister JP (1978a) The impact of river discharge on distribution and production of the school prawn Metapenaeus macleayi (Haswell) (Crustacea; Penaeidae) in the Clarence River region of northern New South Wales. Aust J Mar Freshwater Res 29:311-323

Glaister JP (1978b) Movement and growth of tagged school prawns, Metapenaeus macleayi (Haswell) (Crustacea; Penaeidae), in the Clarence River region of northern New South Wales. Aust J Mar Freshwater Res 29: 645-657

Gould DM, Gallagher ED (1990) Field measurement of specific growth rate, biomass, and primary production of benthic diatoms of Savin Hill Cove, Boston. Limnol Oceanogr 35:1757-1770

> Hamilton SK, Gehrke PC (2005) Australia's tropical river systems: current scientific understanding and critical knowledge gaps for sustainable management. Mar Freshw Res 56:243-252

Harris GP (2001) Biogeochemistry of nitrogen and phosphorus in Australian catchments, rivers and estuaries: effects of land use and flow regulation and comparisons with global patterns. Mar Freshw Res 52:139-149

Harrison PJ, Yin K, Lee JHW, Gan J, Liu H (2008) Physicalbiological coupling in the Pearl River Estuary. Cont Shelf Res 28:1405-1415

Henley WJ, Ramus J (1989) Photoacclimation of Ulva rotundata (Chlorophyta) under natural irradiance. Mar Biol 103:261-266

Irwin AJ, Finkel ZV, Schofield OME, Falkowski PG (2006) Scaling-up from nutrient physiology to the size-structure of phytoplankton communities. J Plankton Res 28: 459-471

- Ives MC, Scandol JP, Montgomery SS, Suthers IM (2009) Modelling the possible effects of climate change on an Australian multi-fleet prawn fishery. Mar Freshw Res 60: $1211-1222$

Johnson P, Fulton E, Smith DC, Jenkins GP, Barrett N (2011) The use of telescoping spatial scales to capture inshore to slope dynamics in marine ecosystem modelling. Nat Resour Model 24:335-364

Kingsford RT, Brandis K, Thomas RF, Crighton P, Knowles E, Gale E (2004) Classifying landform at broad spatial scales: the distribution and conservation of wetlands in New South Wales, Australia. Mar Freshw Res 55:17-31

Kirkman H, Cook IH, Reid DD (1982) Biomass and growth of Zostera capricorni aschers. in Port Hacking, N.S.W., Australia. Aquat Bot 12:57-67 
Laegdsgaard P (2006) Ecology, disturbance and restoration of coastal saltmarsh in Australia: a review. Wetl Ecol Manag 14:379-399

Lancaster G (1990) Physiochemical conditions and seasonal changes in Wooloweyah Lagoon, Yamba NSW. Bachelors Honours thesis, Southern Cross University, Lismore

Lee SY, Dunn RJK, Young RA, Connolly RM and others (2006) Impact of urbanization on coastal wetland structure and function. Austral Ecol 31:149-163

Lehrter JC (2008) Regulation of eutrophication susceptibility in oligohaline regions of a northern Gulf of Mexico estuary, Mobile Bay, Alabama. Mar Pollut Bull 56:1446-1460

> Levins R (1974) The qualitative analysis of partially specified systems. Ann N Y Acad Sci 231:123-138

> Lucas LV, Koseff JR, Monismith SG, Cloern JE, Thompson JK (1999) Processes governing phytoplankton blooms in estuaries. II: The role of horizontal transport. Mar Ecol Prog Ser 187:17-30

Manly Hydraulics Laboratory (1995) Clarence River data compilation study, Report MHL662. NSW Department of Public Works and Services Report No. 93076

Manly Hydraulics Laboratory (2000) Clarence River Estuary processes study, Report MHL971. NSW Department of Public Works and Services

> Murray A, Parslow J (1999) Modelling of nutrient impacts in Port Philip bay - a semi enclosed marine Australian ecosystem. Mar Freshw Res 50:597-611

> Murrell MC, Hagy JD, Lores EM, Greene RM (2007) Phytoplankton production and nutrient distributions in a subtropical estuary: importance of freshwater flow. Estuaries Coasts 30:390-402

> Nobre AM, Ferreira JG, Nunes JP, Yan X and others (2010) Assessment of coastal management options by means of multilayered ecosystem models. Estuar Coast Shelf Sci 87:43-62

Paerl HW (2010) Coastal lagoons: critical habitats of environmental change. CRC Press, Boca Raton, FL

Passow U (1991) Species-specific sedimentation and sinking velocities of diatoms. Mar Biol 108:449-455

Pease BC, Grinberg A (1995) New South Wales commercial fisheries statistics 1940 to 1992. NSW Fisheries, Cronulla

> Pedersen MF, Borum J (1996) Nutrient control of algal growth in estuarine waters. Nutrient limitation and the importance of nitrogen requirements and nitrogen storage among phytoplankton and species of macroalgae. Mar Ecol Prog Ser 142:261-272

> Pollard DA, Hannan JC (1994) The ecological effects of structural flood mitigation works on fish habitats and fish communities in the lower Clarence River system of South-Eastern Australia. Estuaries 17:427-461

> Polyakov V, Fares A, Ryder MH (2005) Precision riparian buffers for the control of nonpoint source pollutant loading into surface water. Environ Rev 13:129-144

Preston BL, Jones RN (2008) Screening climatic and nonclimatic risks to Australian catchments. Geogr Res 46: 258-274

Ramsey D, Veltman C (2005) Predicting the effects of perturbation on ecological communities: What can qualitative models offer? J Anim Ecol 74:905-916

Rayment GE (2003) Water quality in sugar catchments of Queensland. Water Sci Technol 48:35-47

Reid DD, Montgomery SS (2005) Creel survey based estimation of recreational harvest of penaeid prawns in four southeast Australian estuaries and comparison with commercial catches. Fish Res 74:169-185
Rissik D, Shon EH, Newell B, Baird ME, Suthers IM (2009) Plankton dynamics due to rainfall, eutrophication, dilution, grazing and assimilation in an urbanized coastal lagoon. Estuar Coast Shelf Sci 84:99-107

> Rivera-Monroy VH, Twilley RR (1996) The relative role of denitrification and immobilization in the fate of inorganic nitrogen in mangrove sediments (Terminor Lagoon, Mexico). Limnol Oceanogr 41:284-296

Rochford DJ (1952) Estuarine hydrological investigations in Eastern Australia, 1940-1950. Oceanographical station list of investigations made by the Division of Fisheries, Vol 5. Commonwealth Scientific and Industrial Research Organization, Melbourne

> Roy PS, Williams RJ, Jones AR, Yassini I and others (2001) Structure and function of south-east Australian estuaries. Estuar Coast Shelf Sci 53:351-384

Rysgaard S, Rysgaard-Petersen N, Sloth NP (1996) Nitrification, denitrification, and nitrate ammonification in sediments of two coastal lagoons in Southern France. Hydrobiologia 329:133-141

Saintilan N, Williams RJ (1999) Mangrove transgression into saltmarsh environments in south-east Australia. Glob Ecol Biogeogr 8:117-124

Stolte W, Riegman R (1995) Effect of phytoplankton cell size on transient-state nitrate and ammonium uptake kinetics. Microbiology 141:1221-1229

> Swaney DP, Scavia D, Howarth RW, Marino RM (2008) Estuarine classification and response to nitrogen loading: insights from simple ecological models. Estuar Coast Shelf Sci 77:253-263

Trimmer M, Nedwell DB, Sivyer DB, Malcolm SJ (1998) Nitrogen fluxes through the lower estuary of the river Great Ouse, England: the role of the bottom sediments. Mar Ecol Prog Ser 163:109-124

> Turner SJ (2007) Growth and productivity of intertidal Zostera capricorni in New Zealand estuaries. NZ J Mar Freshw Res 41:77-90

> Valiela I, Cole ML (2002) Comparative evidence that salt marshes and mangroves may protect seagrass meadows from land-derived nitrogen loads. Ecosystems 5: 92-102

> Verdy A, Follows M, Flierl G (2009) Optimal phytoplankton cell size in an allometric model. Mar Ecol Prog Ser 379: $1-12$

> Viaroli P, Bartoli M, Giordani G, Naldi M, Orfanidis S, Zaldivar JM (2008) Community shifts, alternative stable states, biogeochemical controls and feedbacks in eutrophic coastal lagoons: a brief overview. Aquat Conserv 18: S105-S117

- Webster IT, Harris GP (2004) Anthropogenic impacts on the ecosystems of coastal lagoons: modelling fundamental biogeochemical processes and management implications. Mar Freshw Res 55:67-78

West RJ, Thorogood C, Walford T, Williams R (1985) An estuarine inventory for New South Wales, Australia. Fisheries Bulletin 2. Department of Agriculture, Cronulla

White N (2009) Wooloweyah Lagoon condition assessment. www.clarence.nsw.gov.au/cmst/cvc009/res.asp?id=6416

Woodward RT, Wui YS (2001) The economic value of wetland services: a meta-analysis. Ecol Econ 37: $257-270$

Yin K (2002) Monsoonal influence on seasonal variations in nutrients and phytoplankton biomass in coastal waters of Hong Kong in the vicinity of the Pearl River estuary. Mar Ecol Prog Ser 245:111-122 
Appendix 1. Adjoint of the community matrices for the estuary channels and Wooloweyah Lagoon

The signed digraph in Fig. 8 has been used to define a matrix of interactions (i.e. the community matrix) that predicted the sign of the response (increase, decrease, or neutral) of each system component to a sustained change (using the adjoint of the community matrix). This approach is referred to as Loop Analysis (Levins 1974) and is described in detail by Dambacher et al. (2003), Ramsey \& Veltman (2005) and at www.ent.orst.edu/loop.

The adjoint matrix for the estuarine channels (upper half of Table A1) indicates that nutrients, phytoplankton and zooplankton all increase in response to more intensive land-use and decrease in response to higher average river discharge or greater habitat coverage. The adjoint matrix for Wooloweyah Lagoon (lower half of Table A1) shows this same qualitative response for land-use and habitat change, but nutrients, phytoplankton and zooplankton all increase with river discharge due to the associated influx of nutrients.

Table A1. The adjoint of the matrices defined by the signed digraph in Fig. 8. The main response in the estuary channels was captured by neglecting the direct interaction of river discharge with nutrients, so that flushing effects dominated (upper half of the table). The main response in Wooloweyah Lagoon was captured by neglecting the direct interaction of river discharge with flushing, so that nutrient effects dominated (lower half of the table). The sign of the adjoint indicates the response direction of dependent components. For example, a sustained increase in agricultural or urban land-use (1st column) would have no effect on flushing (indicated by 0 ) but would increase nutrients, phytoplankton and zooplankton (as indicated by a positive number). Note that, for the purposes of this analysis, habitat change is an externally perturbed element and not influenced by any feedbacks (Fig. 8). Elements with an asterisk are the most significant responses according to the CREAM scenario results

\begin{tabular}{|c|c|c|c|c|c|c|c|}
\hline \multirow{2}{*}{ Responses } & \multicolumn{3}{|c|}{ Perturbed quantities (scenarios) } & \multirow{2}{*}{$\overline{\text { Flushing }}$} & \multicolumn{2}{|c|}{ Perturbed quantities (other) } & \multirow[b]{2}{*}{$\begin{array}{c}\text { Zoo- } \\
\text { plankton }\end{array}$} \\
\hline & Land-use & $\begin{array}{c}\text { River } \\
\text { discharge }\end{array}$ & $\begin{array}{l}\text { Habitat } \\
\text { change }\end{array}$ & & Nutrients & $\begin{array}{l}\text { Phyto- } \\
\text { plankton }\end{array}$ & \\
\hline \multicolumn{8}{|c|}{ Excluding direct river discharge-nutrient interaction } \\
\hline Land-use & 1 & 0 & 0 & 0 & 0 & 0 & 0 \\
\hline River discharge & 0 & 1 & 0 & 0 & 0 & 0 & 0 \\
\hline Habitat change & 0 & 0 & 1 & 0 & 0 & 0 & 0 \\
\hline Flushing & 0 & 1 & 0 & 1 & 0 & 0 & 0 \\
\hline Nutrients & 1 & $-1^{*}$ & -1 & -1 & 1 & 0 & 0 \\
\hline Phytoplankton & 1 & $-2^{*}$ & -1 & -2 & 1 & 1 & 0 \\
\hline Zooplankton & 1 & $-3^{*}$ & -1 & -3 & 1 & 1 & 1 \\
\hline \multicolumn{8}{|c|}{ Excluding direct river discharge-flushing interaction } \\
\hline Land-use & 1 & 0 & 0 & 0 & 0 & 0 & 0 \\
\hline River discharge & 0 & 1 & 0 & 0 & 0 & 0 & 0 \\
\hline Habitat change & 0 & 0 & 1 & 0 & 0 & 0 & 0 \\
\hline Flushing & 0 & 0 & 0 & 1 & 0 & 0 & 0 \\
\hline Nutrients & $1^{*}$ & 1 & -1 & -1 & 1 & 0 & 0 \\
\hline Phytoplankton & $1^{*}$ & 1 & $-1^{*}$ & -2 & 1 & 1 & 0 \\
\hline Zooplankton & $1^{*}$ & 1 & $-1^{*}$ & -3 & 1 & 1 & 1 \\
\hline
\end{tabular}

Editorial responsibility: Ronald Kiene, Mobile, Alabama, USA
Submitted: August 1, 2011; Accepted: March 9, 2012

Proofs received from author(s): June 7, 2012 